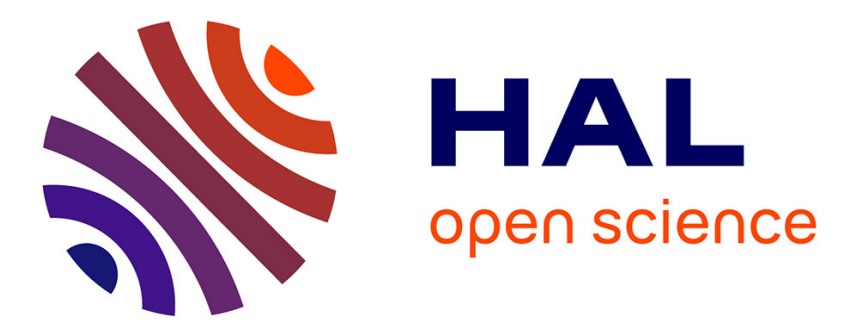

\title{
Dynamics and fates of trace metals chronically input in a Mediterranean coastal zone impacted by a large urban area
}

B Oursel, Cédric Garnier, Gaël Durrieu, Stéphane Mounier, D Omanovic, Yves Lucas

\section{- To cite this version:}

B Oursel, Cédric Garnier, Gaël Durrieu, Stéphane Mounier, D Omanovic, et al.. Dynamics and fates of trace metals chronically input in a Mediterranean coastal zone impacted by a large urban area. Marine Pollution Bulletin, 2013, 69, pp.137-149. 10.1016/j.marpolbul.2013.01.023 . hal-01097079

\section{HAL Id: hal-01097079 \\ https://hal-univ-tln.archives-ouvertes.fr/hal-01097079}

Submitted on 5 Jan 2015

HAL is a multi-disciplinary open access archive for the deposit and dissemination of scientific research documents, whether they are published or not. The documents may come from teaching and research institutions in France or abroad, or from public or private research centers.
L'archive ouverte pluridisciplinaire HAL, est destinée au dépôt et à la diffusion de documents scientifiques de niveau recherche, publiés ou non, émanant des établissements d'enseignement et de recherche français ou étrangers, des laboratoires publics ou privés. 
Provided for non-commercial research and education use. Not for reproduction, distribution or commercial use.

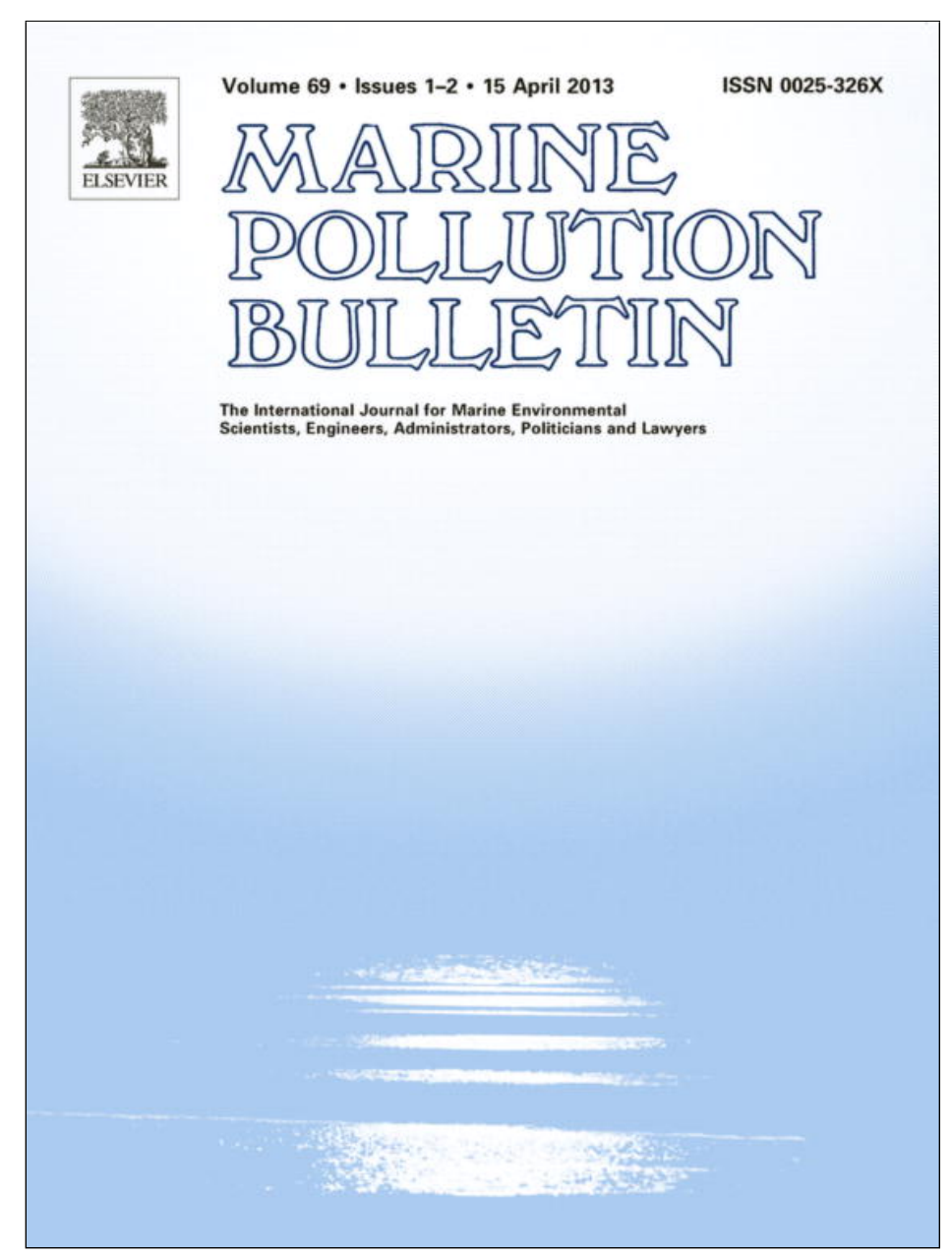

This article appeared in a journal published by Elsevier. The attached copy is furnished to the author for internal non-commercial research and education use, including for instruction at the authors institution and sharing with colleagues.

Other uses, including reproduction and distribution, or selling or licensing copies, or posting to personal, institutional or third party websites are prohibited.

In most cases authors are permitted to post their version of the article (e.g. in Word or Tex form) to their personal website or institutional repository. Authors requiring further information regarding Elsevier's archiving and manuscript policies are encouraged to visit:

http://www.elsevier.com/authorsrights 


\title{
Dynamics and fates of trace metals chronically input in a Mediterranean coastal zone impacted by a large urban area
}

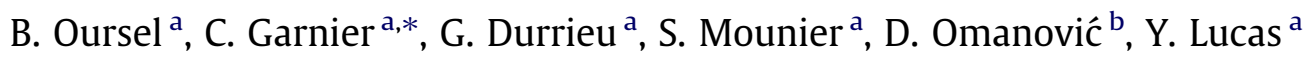 \\ a Université de Toulon, PROTEE, EA 3819, 83957 La Garde, France \\ ${ }^{\mathrm{b}}$ Ruđer Bošković Institute, Center for Marine and Environmental Research, PO Box 180, 10002 Zagreb, Croatia
}

\section{A R T I C L E I N F O}

\section{Keywords:}

TWW

Urban rivers

Metal contamination

Coastal zone

Dry period

\begin{abstract}
A B S T R A C T
Quantification and characterization of chronic inputs of trace metals and organic carbon in a coastal Mediterranean area (the city of Marseille) during the dry season was carried out. The $625 \mathrm{~km}^{2}$ watershed includes two small coastal rivers whose waters are mixed with treated wastewater (TWW) just before their outlet into the sea. Dissolved and particulate $\mathrm{Cu}, \mathrm{Pb}, \mathrm{Cd}, \mathrm{Zn}, \mathrm{Co}, \mathrm{Ni}$ and organic carbon concentrations in the rivers were comparable to those in other Mediterranean coastal areas, whereas at the outlet, 2- to 18-fold higher concentrations reflected the impact of the TWW. A non-conservative behavior observed for most of the studied metals in the mixing zone was validated by a remobilization experiment performed in the laboratory. The results showed that sorption/desorption processes could occur with slow kinetics with respect to the mixing time in the plume, indicating non-equilibrium in the dissolved/particulate metal distribution. Thus, a sample filtration immediately after sampling is strictly required.
\end{abstract}

(c) 2013 Elsevier Ltd. All rights reserved.

\section{Introduction}

Progressive anthropization of coastal areas throughout the world results in changes in the biology and chemistry of coastal seawaters that can drastically alter their ecological and biological dynamics. Coastal inputs of anthropogenic nutrients and contaminants by rivers have proved to play key roles in these changes. Trace metals are of concern because of their potential for longterm accumulation in soils and sediments. Trace metals are natural constituents of crustal materials and can enter into aquatic system through erosion processes (Di Leonardo et al., 2009; Rocha et al., 2011; Weber et al., 2009). Some metals are essential to biota, but all have the potential to be biologically toxic if their concentrations exceed certain levels. Anthropogenic inputs of trace metals to the aquatic compartment often exceed the contributions from natural sources, especially where population density is high. These anthropogenic inputs are mainly due to leaching of impervious urban surfaces (roads, parking lots and roofs) and soil surfaces by runoff and to sewage overflow from sanitary sewer systems during high rainfall events; locally treated wastewater (TWW) discharges and industrial effluents can also be of importance (Bay et al., 2003; Bothner et al., 2002; Gonzalez et al., 1999; Matthai et al., 2002; Nicolau et al., 2012). Wastewater treatment plants have been designed to remove nutrients from wastewaters, but it is also known that large amounts of potentially toxic elements such as metals

\footnotetext{
* Corresponding author. Tel.: +33 494142099; fax: +33 494142168.

E-mail address: cgarnier@univ-tln.fr (C. Garnier).
}

end up in wastewater. Until recently, the concentrations of trace metals in the effluents from waste water treatment plants (WWTPs) were not routinely tested because of high monitoring costs (Busetti et al., 2005).

The behavior of trace metals discharging in a coastal zone from a freshwater input depends on the properties of their species and the time of mixing. The differences in physico-chemical conditions between river water and seawater can cause a redistribution of metals between solution and suspended particulate matter (SPM) phases. Mobilization of dissolved metals from the solid phase is, indeed, the subject of considerable interest, and numerous field data confirm the significance of metal release from river SPM in salinity gradients (Kraepiel et al., 1997). During the mixing of fresh and salty waters, the partitioning of metallic species between the solution and SPM phases is controlled by two major processes: the removal of metals by flocculation of humic and fulvic acid-metal complexes and the desorption of metals from river particles or from resuspended sediment (Roux et al., 1998; Wang and Liu, 2003). Trace metal behavior varies according to metal and estuary. Conservative behavior was reported for $\mathrm{Cu}$ in the Rhône estuary (Dai et al., 1995; Elbaz-Poulichet et al., 1996), the Gironde estuary (Kraepiel et al., 1997) and the Loire estuary (Waeles et al., 2009), for $\mathrm{Zn}$ in the Scheldt estuary (Zwolsman et al., 1997) and for Pb in the Gironde estuary (Kraepiel et al., 1997). Contrastingly, Cu release into solution was shown in the Changjiang Estuary (Wang and Liu, 2003), the San Francisco Bay Estuary (Sañudo-Wilhelmy et al., 1996) and the Penze Estuary (Waeles et al., 2008). Cd also showed non-conservative behavior in various estuaries 
(e.g., Elbaz-Poulichet and Martin, 1987; Waeles et al., 2009). The characteristics of a river or estuary's watershed such as climate (e.g., rain frequency and intensity), morphology, hydrology, geology and land use drive estuarine dynamics, particularly flushing times of waters and particle concentrations and residence times, which are among the most important factors controlling metal reactivity in estuaries (Elbaz-Poulichet, 2005). Additional parameters such as redox conditions (Zwolsman et al., 1997) or presence of dissolved organic matter (DOM) (Louis et al., 2009) have also been reported to control the fate of metals in estuaries. In aquatic systems, DOM plays a major role in metal speciations, affecting their bioavailability and toxicity towards micro- and macro-organisms (Bruland and Lohan, 2003). Among possible DOM sources, WWTP effluents bring high quantities of dissolved and particulate carbon forms to rivers or estuaries, influencing metal speciations significantly, which implies a need for DOM characterization (e.g., Buzier et al., 2011; Pernet-coudrier et al., 2008).

Only a few studies have dealt with the Mediterranean area despite its rapid anthropization due to present-day heliotropism from Northern Europe and despite its climate specificities. Among all the possible sources of marine pollution, large coastal cities are among the most worrying, especially in the Mediterranean Sea. A typical example is Marseille, the largest Mediterranean French city, with over 1.7 million inhabitants. Two small rivers, the Huveaune and the Jarret, run through the agglomeration and join before their outlet to the sea (Fig. 1). Despite their low flow, they can have a large local ecological impact. Some studies have been performed on the dynamics of elements in Mediterranean estuaries of large or small rivers (e.g., Dassenakis et al., 1997; Elbaz-Poulichet et al., 1991; Elbaz-Poulichet, 2005; Ollivier et al., 2011), but a system such as Marseille is not commonly examined. The uniqueness of this system is that the river waters are mixed with the city WWTP effluents and then rapidly discharged into the open sea without passing through an estuary, so that the WWTPs' contribution to the water characteristics at the outlet is most likely predominant during baseflow periods. These inputs have a certain impact on the local coastal ecosystem, however, a high number of such anthropized sources along the coast is likely to impact the whole Mediterranean Sea.

In this context, the aims of the present study were (1) to quantify and characterize carbon and trace metal inputs to the sea during dry periods near the Marseille urban area, (2) to identify the specific contribution of the WWTP and (3) to understand the transfer mechanisms that operate in the mixing zone.

\section{Materials and methods}

\subsection{Study site}

The climate of the studied area is typically Mediterranean, with wet temperate winters and dry, hot summers. The average annual rainfall is $551 \mathrm{~mm}$. Rainfall is strongly seasonal as more than 75\% of the rains occur between September and January. The rains are frequently of high intensity, promoting high rates of terrestrial runoff and can occur after long, dry periods that allow contaminant accumulation on the watershed surfaces. Another rainfall period occurs in spring between March and May, during which rainfalls can be of longer duration and lower intensity. Long dry periods (less than $30 \mathrm{~mm}$ of rain per month) occur from January to March and from May to September. As in most of the Mediterranean area, the spatial and seasonal variability of the rainfall follows a complex pattern with wide and unpredictable rainfall fluctuations from 1 year to another (Martínez-Casasnovas et al., 2002).

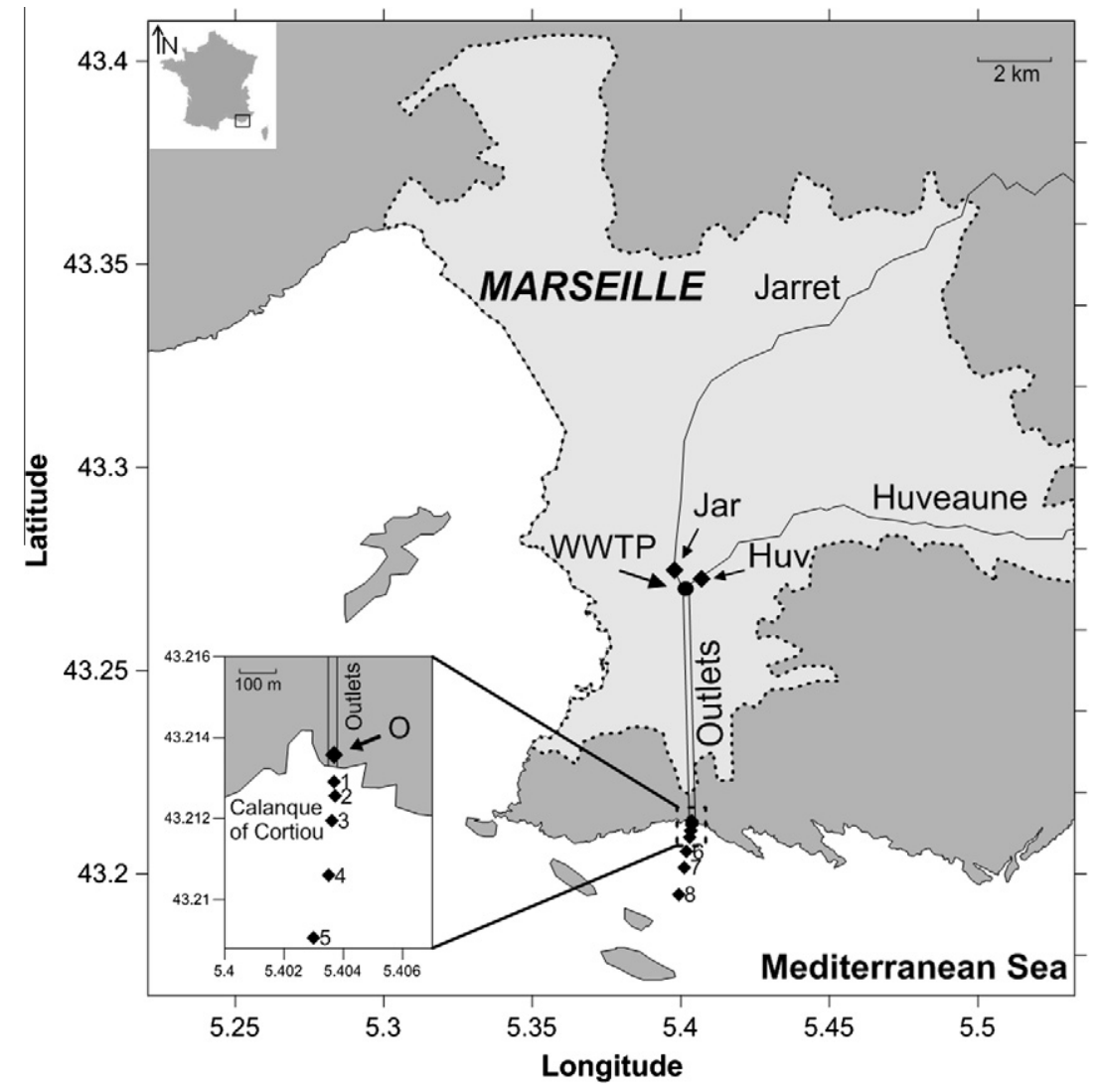

Fig. 1. Map of the studied site: the dotted area represents the urbanized zone of Marseille, (inset) position of the sampling sites, in the vicinity of the effluent outlets. Sampling points: O: outlet; Jar: Jaret River; Huv: Huveaune River; 1-8: surface sampling points at sea. 
The Huveaune River extends over $48.4 \mathrm{~km}$ and runs through a watershed with an area of $523 \mathrm{~km}^{2}$ that consists of a karstic formation (60\%) and detrital sediments. Land use in the downstream part of the watershed is urban and industrial. The Jarret extends over $21 \mathrm{~km}$ with a $102 \mathrm{~km}^{2}$ watershed that is mainly urban and industrial. These two rivers merge in Marseille. The resulting river water is mixed with the effluent water coming from the Marseille City WWTPs and then channeled to the sea at the Calanque of Cortiou (Fig. 1). This treatment plant, one of the largest in Europe (1.7 million inhabitant eq.), uses both physical and biological treatment processes. At the Calanque of Cortiou, freshwater-seawater mixing occurs directly at the surface of the sea and presents a rapid mixing time.

The Huveaune's base flow ranges from 1 to $5 \mathrm{~m}^{3} \mathrm{~s}^{-1}\left(1.7 \mathrm{~m}^{3} \mathrm{~s}^{-1}\right.$ on average), the Jarret's from 0.5 to $3\left(0.8 \mathrm{~m}^{3} \mathrm{~s}^{-1}\right.$ on average) and the WWTPs' effluent ranges from 0.4 to $3.8 \mathrm{~m}^{3} \mathrm{~s}^{-1}\left(3.0 \mathrm{~m}^{3} \mathrm{~s}^{-1}\right.$ on average), so that half of the flow at the outlet is due to the WWTP discharge.

\subsection{Sampling}

All bottles (FEP and HPED, from Nalgene) used throughout the sampling and conditioning were previously cleaned with $10 \%$ nitric acid prepared from $70 \% \mathrm{HNO}_{3}$ of analytical reagent grade (Fisher Scientific), rinsed with milli-Q water (Millipore $18.2 \mathrm{M} \Omega$ ), filled with milli-Q water and acidified at $0.1 \%$ with s.p. $\mathrm{HNO}_{3}$ (Merck) until use.

Five sampling campaigns (16/02/2010, 18/03/2010, 26/04/2010, $28 / 06 / 2010,22 / 03 / 2011$ ) were conducted during dry periods but under contrasting conditions with regard to season, wind and waves. A sixth campaign conducted on 18/04/2012 allowed identification of an abnormal event characterized by very high DOC and metal concentrations and will be discussed separately in the text. For tributaries, 15 (Huveaune, Jarret) and 25 (Outlet) additional samples were collected at various dates in between these campaigns to better take into account input variabilities and thereby evaluate more accurately their contributions to the average flux of elements to the coastal zone.

Sampling locations (Fig. 1, inset) were selected to cover the whole freshwater-seawater mixing zone. Eight profiles of salinity, temperature and dissolved $\mathrm{O}_{2}$ were assessed along a north-south transect from the outlet to over $2 \mathrm{~km}$ offshore using a HACH LANGE multi-probe calibrated before each campaign.

Surface samples were collected in the Huveaune and Jarret Rivers upstream of their confluence, while mixed river and WWTP water was collected just upstream of the outlet (continental endmember). Along a transect at sea, four samples were taken at $\approx 5 \mathrm{~m}$ from the outlet (surface, $0.5,1.5$ and $2.5 \mathrm{~m}$ in depth), two samples at $2 \mathrm{~km}$ offshore (surface and $4 \mathrm{~m}$ in depth, this latter defining the marine end-member), and six surface samples between these two limits. Considering the high salinity stratification of the plume, sampling was performed using a $2.2 \mathrm{~L}$ horizontal sampler (Wildco) that allowed a $10-\mathrm{cm}$ thick water layer resolution. Samples were partitioned in $1 \mathrm{~L}$ FEP bottles for metal analysis and $1 \mathrm{~L}$ HDPE bottles for organic matter (OM) analysis. After sampling, the bottles were stored in a cooler, brought back to the laboratory and immediately filtered. Additionally, during the two last campaigns, at each sampling site, an aliquot was also immediately filtered on board.

\subsection{Sample filtration, conditioning and treatment}

Samples for DOC/POC analyses were filtered through $25 \mathrm{~mm}$ glass filters (Whatman GFF, $0.7 \mu \mathrm{m}$ ). Particulate organic carbon (POC) was quantified using these filters. The dissolved fraction was preserved using $25 \mu \mathrm{L} 1 \mathrm{M} \mathrm{NaN}_{3}\left(\mathrm{NaN}_{3}>99 \%\right.$, Aldrich $)$ and stored at $4{ }^{\circ} \mathrm{C}$ in $24 \mathrm{~mL}$ glass tubes (Wheaton, equipped with Teflon/silicone septa) prior to analysis of dissolved organic carbon (DOC). All tubes, filters and glass filtering systems (Wheaton) were previously cleaned with $10 \% \mathrm{HNO}_{3}$, milli-Q rinsed and calcinated for $4 \mathrm{~h}$ at $450{ }^{\circ} \mathrm{C}$.

Samples stored in $1 \mathrm{~L}$ FEP bottles for dissolved/particulate metal analyses were filtered through $47 \mathrm{~mm}$ cellulose nitrate filters (Sartorius, $0.45 \mu \mathrm{m}$ ). The filters were dissolved by microwave digestion (AntonPaar Multiwave 3000) in aqua regia (trace metal grade acids, Fisher Scientific) for further analysis of metals in the particulate fraction following a previously validated procedure (Tessier et al., 2011). The filtrate (dissolved fraction) was stored in $60 \mathrm{~mL}$ FEP bottles, acidified with $60 \mu \mathrm{L} \mathrm{HNO}_{3}$ (supra pure 65\%, Merck) and digested for $2 \mathrm{~h}$ under UV irradiation (Metrohm 705, $500 \mathrm{~W}$ ) for further analysis of total dissolved metal concentrations (Louis et al., 2009).

Onboard filtration was achieved using $0.2 \mu \mathrm{m}$ in-line syringe cellulose nitrate filters (Sartorius). Filtrates were stored in $60 \mathrm{~mL}$ FEP bottles for dissolved metal analysis and in $24 \mathrm{~mL}$ glass tubes for DOC analysis. Similar conditioning protocols were applied as for the laboratory-filtered samples.

\subsection{Remobilization experiment}

For a better understanding of the mechanisms that operate in the salinity gradient, a remobilization experiment designed to simulate the mixing of the outlet effluent with seawater was performed in the laboratory. A $10 \mathrm{~L}$ sample of composite outlet water was obtained during the 28 June 2010 campaign by collecting ten $1 \mathrm{~L}$ samples during $\sim 15 \mathrm{~min}$ to obtain a representative outlet sample. Filtered marine end-member water was mixed in $1 \mathrm{~L}$ FEP bottles with the unfiltered outlet water to cover a range of salinity: $1,2.5,5,10$ and 25 . The $1 \mathrm{~L}$ FEP bottles were placed on an agitation system (Reax 20, Heildolph) and aliquots were sampled at $15 \mathrm{~min}, 1$ and $6 \mathrm{~h}$ of mixing time using pre-cleaned syringes and then filtered through pre-cleaned $0.22 \mu \mathrm{m}$ in-line filters (Sartorius). Filtrates were stored and analyzed for DOC and dissolved trace metals as explained below.

\subsection{One-day monitoring of the outlet waters}

A 1-day monitoring of the outlet effluent was performed from $21 / 03 / 201121 \mathrm{~h}$ to $22 / 03 / 201121 \mathrm{~h}$ using a mobile refrigerated automatic sampler (Hydreka) installed in the outlet upstream of the mixing of the TWW with the river waters, thanks to the logistics of the SERAM company. In all, 24 1-L composite samples were each collected by sampling $100 \mathrm{ml}$ of water every 6 min over the course of $1 \mathrm{~h}$. The samples were then treated in the laboratory using the protocol described previously.

\subsection{Carbon analysis}

POC contents on filters were determined using a TOC- $\mathrm{V}_{\mathrm{CSH}}$ analyzer (Shimadzu), coupled with an SSM-5000A module. The GFF filters were dried to constant weight at $60^{\circ} \mathrm{C}$, and then exposed to $\mathrm{HCl}$ fumes for $4 \mathrm{~h}$ to remove all of the inorganic carbon (Lorrain et al., 2003). The organic carbon content was determined using the high-temperature $\left(900^{\circ} \mathrm{C}\right)$ catalytic oxidation method with $\mathrm{CO}_{2}$ IR detection (Ammann et al., 2000; Callahan et al., 2004), calibrated using glucose (Analytical reagent grade, Fisher Scientific), with an accuracy of $0.1 \mathrm{mg}$ C.

DOC and DIC concentrations were determined using the same TOC- $\mathrm{V}_{\mathrm{CSH}}$ analyzer, calibrated using hydrogenophtalate (Shimadzu) and $\mathrm{NaHCO}_{3} / \mathrm{Na}_{2} \mathrm{CO}_{3}$ standard solutions, respectively, with an accuracy of $0.02 \mathrm{mg} \mathrm{C} \mathrm{L}^{-1}$ (Louis et al., 2009). DOC and DIC anal- 
yses were validated using a certified reference material (MISSIPPI03, Canada); values obtained remained within the certified limits.

\subsection{Analyses of major elements and trace metals}

\subsubsection{Dissolved trace metals in salt samples}

Total dissolved metal $(\mathrm{Cd}, \mathrm{Cu}, \mathrm{Pb}$ and $\mathrm{Zn})$ concentrations were determined using Differential Pulse Anodic Stripping Voltammetry (DPASV). Measurements were carried out using an AutolabIII (EcoChemie) potentiostat controlled by GPES 4.9 software (EcoChemie) coupled with a three-electrode cell (663 VA Stand, Metrohm) (Louis et al., 2009) with a $\mathrm{Ag}|\mathrm{AgCl}| \mathrm{KCl} 3 \mathrm{M}$ electrode as the reference, a Pt wire as the auxiliary and a static mercury drop (SMDE) as the working electrode. Parameters of the DPASV procedures were adapted from (Omanović et al., 2006) and (Jean et al., 2012). Total dissolved $\mathrm{Co}$ and Ni were determined only for samples of the last three campaigns using Differential Pulse Adsorptive Cathodic Stripping Voltammetry (DPAdCSV) using the same instrument and a procedure adapted from (Vega and van den Berg, 1997). Trace metal determinations were performed using a fully automatic standard addition method using Cavro XE 1000 Syringe Pumps and the voltammograms obtained were treated (2nd derivative) using ECDSOFT software (Omanović et al., 2006). Standard deviations of the measured metal concentrations remained below $5 \%$.

Analyses were validated using a certified "Nearshore Seawater Reference Material for Trace Metals" - CASS5 (NRC CNRC). All metal determinations remained within the certified limits.

\subsubsection{Major ions in freshwater samples}

Major ions were analyzed using ionic chromatography (Dionex, DX-120) to measure $\mathrm{F}^{-}, \mathrm{Cl}^{-}, \mathrm{SO}_{4}^{2-}, \mathrm{Na}^{+}, \mathrm{NH}_{4}^{+}, \mathrm{K}^{+}, \mathrm{Mg}^{2+}$ and $\mathrm{Ca}^{2+}$. Anionic and cationic columns were loaded with quaternary ammonium- (AS9-HC) or carboxylate-functionalized (CS12-A) groups, respectively. Anionic and cationic eluents were $9 \mathrm{mM} \mathrm{Na}_{2} \mathrm{CO}_{3}$ and $20 \mathrm{mM} \mathrm{CH}_{4} \mathrm{SO}_{3}$, respectively. In both cases, the flow rate was

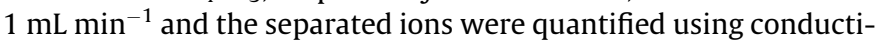
metry. Analyses were validated using a "River Water Reference Material” (MISSIPPI-03, Environment Canada).

\subsubsection{Trace dissolved metals in freshwater samples and particulate metals}

Particulate metals on the acid-digested filters were quantified using High Resolution Inductively Coupled Plasma Mass Spectrometry (HR ICP-MS Element 2, Thermo Finnigan). The instrument was calibrated using standard solutions and an In internal standard was added to the samples (Lenoble et al., 2013). Quality control of the HR ICP-MS measurements was performed by determination of element concentrations in a Certified Reference Material (SLRS-4 river water, PACS-2 sediment, National Research Council Canada). All results showed good agreement with the certified data. Trace metal concentrations in the freshwater samples were analyzed following the same procedure.

In the following, concentration and content terms refer to mass/ mol per unit volume (e.g., $\mathrm{mg} \mathrm{L}^{-1}$ ) and mass/mol per unit mass (e.g., $\mathrm{mg} \mathrm{g}^{-1}$ ), respectively.

\section{Results and discussion}

\subsection{Dynamics of elements in the mixing zone}

Table 1 gives the averages and ranges of variation of the measured parameters in the Huveaune and Jarret Rivers, at the outlet and in the seawater end-member compared with the world averages for rivers (Gaillardet et al., 2003) and with values observed in the Eygoutier River, a small coastal river in the same geographic area (Nicolau et al., 2012).

\subsubsection{Salinity, dissolved oxygen and SPM}

The dispersion of freshwater in seawater during dry weather conditions can be tracked according to salinity (Supplementary material Fig. SI1). The sea salinity near Marseille is approximately 38.2. The river/effluent outlet salinity, which is lower than 0.5 , will be considered as null. The freshwater plume thickness decreased from 4 to $1 \mathrm{~m}$ along the first $400 \mathrm{~m}$ of the transect and then remained lower than $1 \mathrm{~m}$ until $1000 \mathrm{~m}$.

In the rivers, dissolved oxygen varied from $98 \%$ to $104.2 \%$ for the Huveaune and from $83.6 \%$ to $94.3 \%$ for the Jarret, values similar to other Mediterranean rivers. In outlet discharge water, dissolved oxygen varied from $69.5 \%$ to $82.2 \%$. The decrease in the dissolved oxygen in the outlet waters was due to high DOC/POC concentrations in the TWW that stimulated oxygen-consuming biologic activity. In the plume, dissolved oxygen increased and closely followed the salinity variation due to dilution with seawater whose oxygen saturation is close to $100 \%$ (Zwolsman et al., 1997).

In Huveaune water, Suspended Particulate Matter (SPM) varied from 2.1 to $21 \mathrm{mg} \mathrm{L}^{-1}$, and in Jarret water, from 4.6 to $30 \mathrm{mg} \mathrm{L}^{-1}$ (Table 1). These values were comparable to those of other Mediterranean rivers such as the Rhone (close to $6 \mathrm{mg} \mathrm{L}^{-1}$ (Ollivier et al., 2011) and the Eygoutier $\left.\left(13 \pm 3.7 \mathrm{mg} \mathrm{L}^{-1}\right)\right)$ under similar conditions. At the outlet, the SPM value was higher (between 9.8 and $83 \mathrm{mg} \mathrm{L}^{-1}$ ) due to the TWW that contained a high quantity of particles. Along the salinity gradient, the SPM was conservative with the salinity and decreased to $4.5 \mathrm{mg} \mathrm{L}^{-1}$ in the seawater end-member, a value typical of the north-east Mediterranean Sea (Chronis et al., 2000). These results indicate that no significant sedimentation processes occurred at the beginning part of the plume, which means that the particles were low-weighted, such as organic matter (OM), or small-sized, such as oxide or clay particles. This suggests that, during dry conditions, no significant sedimentation occurs and that most of the metal and OM inputs from the Marseille urban area remain suspended in seawater.

\subsubsection{Organic matter}

DOC and POC variations as functions of salinity are given in Fig. 2. Throughout the campaigns, DOC concentrations varied from 1 to $1.8 \mathrm{mg} \mathrm{C} \mathrm{L}^{-1}$ in the Huveaune and from 1.1 to $2.9 \mathrm{mg} \mathrm{C} \mathrm{L}^{-1}$ in the Jarret (Table 1 ). These values are in the range of those observed in the Eygoutier River $\left(4.1 \pm 3.5 \mathrm{mg} \mathrm{C} \mathrm{L}^{-1}\right)$ and in the Rhône river (1.7 $\mathrm{mg} \mathrm{C} \mathrm{L}^{-1}$, (Dai et al., 1995)). At the outlet, the DOC fluctuated from 4 to $10 \mathrm{mg} \mathrm{C} \mathrm{L}^{-1}$ (6.2 $\mathrm{mg} \mathrm{C} \mathrm{L}^{-1}$ on average), these high values being explained by the DOC concentrations in the TWW being higher than $40 \mathrm{mg} \mathrm{C} \mathrm{L}^{-1}$ as observed by Drewes and Jekel (1998). In the mixing zone, the DOC concentration progressively decreased to less than $1 \mathrm{mg} \mathrm{C} \mathrm{L}^{-1}$ in the seawater end-member, following the mixing line, which indicates conservative behavior (Fig. 2A). The same behavior was observed in various estuaries such as the Rhône Estuary (Dai et al., 1995), the Mississippi River plume (Guo et al., 2009) and the Bay of Saint Louis (Cai et al., 2012) as well as the Humber Estuary (Álvarez-Salgado and Miller, 1998; Cai et al., 2012). As observed in other studies, increased DOC at low salinity was due to (1) lysis of freshwater phytoplankton cells in seawater (Morris et al., 1978), (2) deflocculation of SPM aggregated colloids affecting only the $<3 \mathrm{~nm}$ DOC fraction (Dai et al., 1995) or (3) bacterial decomposition of SPM-OM where turbidity is high (ÁlvarezSalgado and Miller, 1998). Such DOC behavior was not observed in the studied system.

Throughout the campaigns, the POC content varied from 55 to $160 \mathrm{mg} \mathrm{C} \mathrm{g}^{-1}$ in Huveaune water, from 130 to $320 \mathrm{mg} \mathrm{C} \mathrm{g}^{-1}$ in Jarret water and from 110 to $420 \mathrm{mg} \mathrm{C} \mathrm{g}^{-1}$ at the outlet (Table 1 ). As for the DOC, higher values and variability at the outlet are ex- 


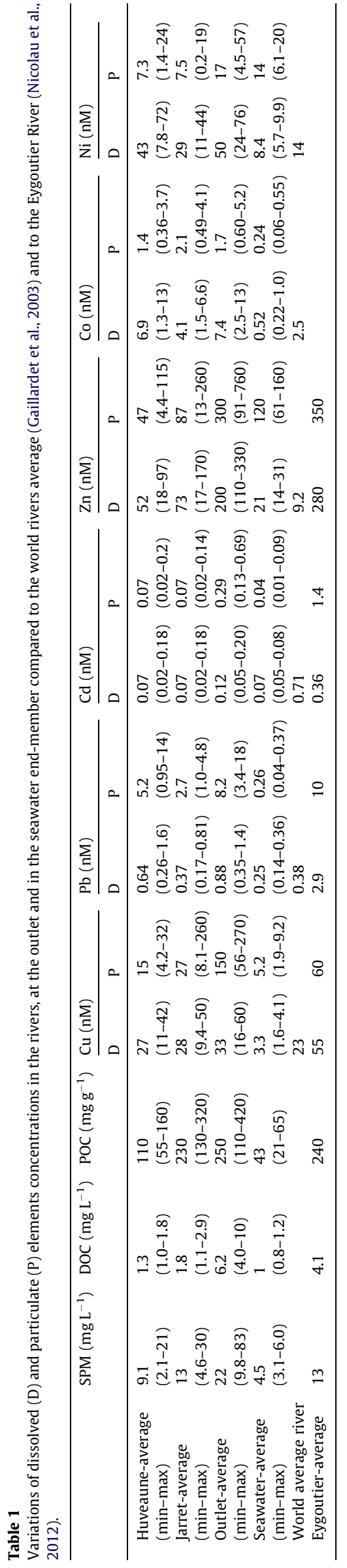

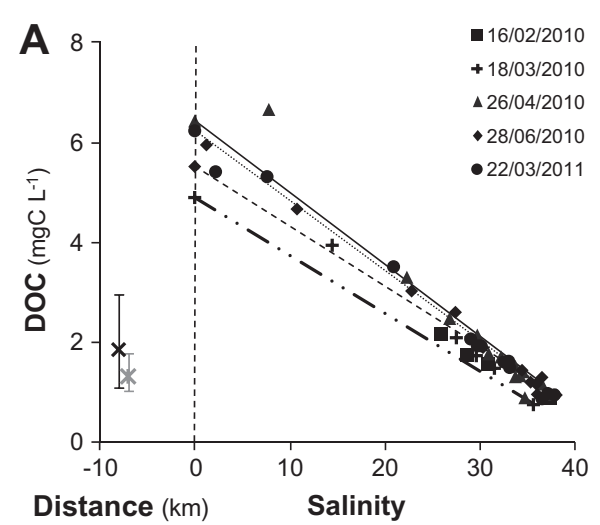

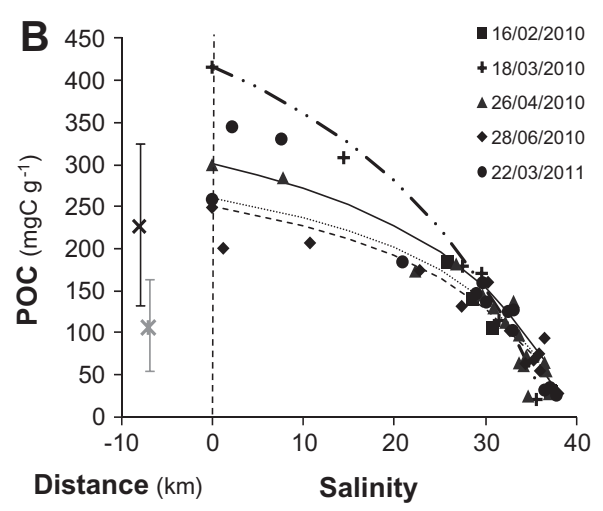

Fig. 2. Variation of DOC $(A)$ and $P O C(B)$ in Huveaune $\left({ }^{*}\right)$ and in Jarret $(x)$ rivers, as a function of the distance until outlet, and from outlet to seawater, as a function of the salinity gradient, for each sampling campaign. Vertical lines at river points join maximum and minimum values. Mixing lines are given for the 18/03/2010 (dotteddashed line), 26/04/2010 (solid line), 28/06/2010 (dotted line) and 22/03/2011 (dashed line) campaigns.

plained by the TWW POC content: at the outlet, the variability of both DOC and POC was controlled by the TWW inputs that were superimposed onto the river fluctuations. For all the campaigns, the POC content decreased with increasing salinity down to the value of the seawater end-member ( $43 \mathrm{mg} \mathrm{C}^{-1}$ on average), as observed elsewhere (Cai et al., 2012; Saliot et al., 2002; Savoye et al., 2012). Globally, the POC content showed a conservative trend for all of the campaigns (Fig. 2B). The sample variability compared to the conservative curve was due to the heterogeneity of the source.

Fig. 3 gives DOC as a function of POC expressed in $\mathrm{mg} \mathrm{C} \mathrm{L}^{-1}$. In the Huveaune, the DOC fraction is dominant, whereas in the Jarret river, it is the POC fraction. Finally, at the outlet, the DOC and POC are in the same range but in higher concentrations, which implies high DOC and POC inputs in the TWW. Along the salinity gradient, the DOC increased from $50 \%$ of the total organic carbon at the outlet to $90 \%$ in the marine end-member as observed elsewhere (Cauwet et al., 1997).

\subsubsection{Dissolved and particulate metals}

Variations of dissolved metal concentration as a function of salinity from the river points to the marine end-member and dissolved concentration as a function of particulate concentration are depicted in Fig. 4 for each metal studied. The eq:eq line permits comparison of dissolved and particulate fractions for the same element. For each element, the Huveaune/Jarret data points and error bars represent average values and min-max ranges, respectively, calculated from the full set of analyzed samples (see Section 2.2). 


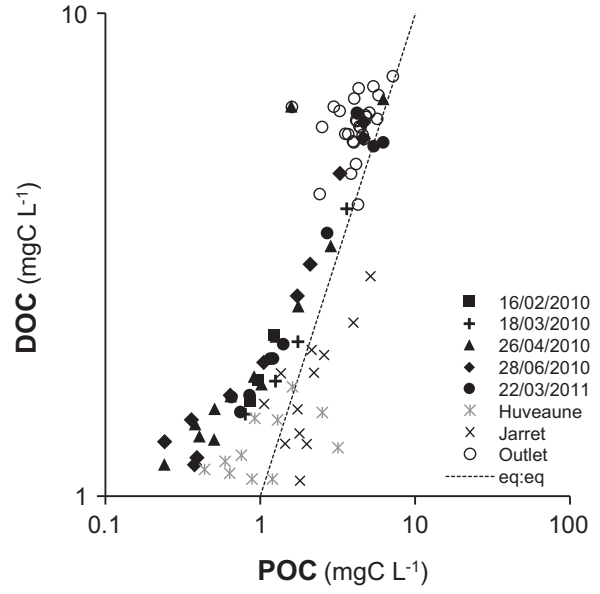

Fig. 3. $D O C$ as a function of $P O C$ expressed in $\mathrm{mg} \mathrm{C} \mathrm{L}^{-1}$. The dotted line (eq:eq) represents the same carbon concentration in the dissolved and particulate phases.

$\mathrm{Cu}$ concentrations measured in the Huveaune and Jarret Rivers were in the same range, either as dissolved or particulate (Table 1), but lower than in the Eygoutier River (Nicolau et al., 2012). Dissolved $\mathrm{Cu}$ was close to the world average river value (Table 1). $\mathrm{Cu}$ was mainly in the dissolved fraction in Huveaune water and equidistributed between the dissolved and particulate fractions in Jarret water (Fig. 4B). The higher particulate/dissolved $\mathrm{Cu}$ ratio at the outlet compared to the rivers indicates a high input of particulate $\mathrm{Cu}$ by the TWW. Dissolved $\mathrm{Cu}$ represented $20 \%$ and $80 \%$ of total $\mathrm{Cu}$ at the outlet and at the marine end-member, respectively. Dissolved $\mathrm{Cu}$ concentrations in the marine end-member (3.3 $\mathrm{nM}$ on average) were in the range of those reported for Western Mediterranean surface water (Morley et al., 1997) and coastal waters of Toulon Bay (Jean et al., 2012). Dissolved Cu at the outlet was therefore 10 times higher than the typical seawater value. Diminution of $\mathrm{Cu}$ with increasing salinity followed different patterns, depending on the campaigns: slightly below the conservative mixing line for the March 2011 campaign, which indicates a probable adsorption of dissolved Cu onto SPM; significantly above the line for the March, April and June 2010 campaigns (Fig. 4A), which indicates, instead, a release of dissolved $\mathrm{Cu}$ from SPM as previously observed in the Loire Estuary (Waeles et al., 2004). This contrasts with the conservative behavior of $\mathrm{Cu}$ reported for the Rhone (Elbaz-Poulichet et al., 1996) and Danube (Guieu et al., 1998) Estuaries.

$\mathrm{Pb}$ was mainly found in the particulate fraction in the Huveaune and Jarret rivers and at the outlet, whereas in the seawater endmember dissolved $\mathrm{Pb}$ was higher (Fig. 4D). In the Huveaune and Jarret rivers, both particulate and dissolved $\mathrm{Pb}$ values were lower than those observed in the Eygoutier River and, regarding dissolved $\mathrm{Pb}$, of the same order of concentration as the world river average (Table 1). Concentrations of both fractions were approximately 2 -fold higher at the outlet than in the rivers, indicating a significant $\mathrm{Pb}$ input from the TWW. Dissolved $\mathrm{Pb}$ represented $15 \%$ and more than $50 \%$ of total $\mathrm{Pb}$ at the outlet and at the seaend-member, respectively. Dissolved $\mathrm{Pb}$ at the marine end-member $(0.25 \mathrm{nM}$ on average) was higher than the average surface $\mathrm{Pb}$ of $0.085 \mathrm{nM}$ measured in western Mediterranean waters (Morley et al., 1997) but was close to the value recorded in the open part of Toulon Bay (0.19 nM, (Jean et al., 2012)). For the April 2010 campaign, dissolved $\mathrm{Pb}$ showed a behavior close to the conservativity in the salinity gradient, as reported for the Gironde (Kraepiel et al., 1997) and in the Rhône Estuaries (Elbaz-Poulichet et al., 1996). For the other campaigns, data points were above the conservative mixing line, indicative of the release of dissolved $\mathrm{Pb}$ from SPM that was maximal at salinities close to 10 (Fig. 4C).
The Huveaune and Jarret Rivers showed the same average concentrations of particulate and dissolved $\mathrm{Cd}$. These values were lower than those observed in the Eygoutier River and than those in the world river average (Table 1 ). Such low dissolved Cd values are likely due to the geology of the Huveaune and Jarret watersheds. The TWW brought particulate Cd in higher proportion compared to the river values (Fig. 4F). Dissolved Cd represented 15\% and more than $90 \%$ of total $\mathrm{Cd}$ at the outlet and at the marine endmember, respectively. Dissolved Cd at the marine end-member ( $0.07 \mathrm{nM}$ on average) was higher than the mean value observed in the 1-100 m layer in the western Mediterranean $(0.044 \mathrm{nM}$, (Morley et al., 1997)) but lower than values observed in the eastern Mediterranean (0.018-0.278 nM, (Zeri and Voutsinou-Taliadouri, 2003)) and close to the ones measured in coastal waters of Toulon Bay (Jean et al., 2012). On average, dissolved Cd was 2-fold more concentrated at the outlet than at the marine end-member. For the April and June 2010 campaigns, points above the conservative mixing line (Fig. 4E) indicate the release of $\mathrm{Cd}$ from particles. This mechanism is well documented and corresponds to the formation of stable and soluble chlorocomplexes from particle-desorbed Cd (Dai and Martin, 1995; Elbaz-Poulichet et al., 1987; Waeles et al., 2008; Wang and Liu, 2003; Yang and Sañudo-Wilhelmy, 1998). This phenomenon was principally observed at salinities greater than 25. Two possibilities were suggested: (1) the desorption was more efficient at high quantities of chlorides, or (2) the mixing time was too short at low salinities to allow release of $\mathrm{Cd}$ into the dissolved phase. On the contrary, the data points for the March 2011 campaign were below the mixing line up to a salinity of 25 and above the mixing line thereafter (Fig. 4E), which indicated an adsorption of $\mathrm{Cd}$ onto particles up to a salinity of 25 followed by a release of $\mathrm{Cd}$ from particles to the dissolved phase above a salinity of 25.

Particulate and dissolved $\mathrm{Zn}$ concentrations in the Huveaune and Jarret Rivers were lower than in the Eygoutier River. At the outlet, they were in the same range as in the Eygoutier River. Dissolved $\mathrm{Zn}$ concentrations in the Huveaune and Jarret rivers were 68 -fold higher than the world river average (Table 1 ). In the rivers, $\mathrm{Zn}$ was evenly distributed between the dissolved and particulate fractions, but at the outlet, particulate $\mathrm{Zn}$ was in higher proportion (Fig. 4H). The dissolved $\mathrm{Zn}$ decreased with increasing salinity from values higher than $110 \mathrm{nM}$ at the outlet to $21 \mathrm{nM}$ at the marine end-member (Fig. 4G), this latter value being higher than those reported in surface Mediterranean waters: $4-5 \mathrm{nM}$ in surface western Mediterranean waters (Morley et al., 1997) and and close to $9 \mathrm{nM}$ in the open part of Toulon Bay (Jean et al., 2012). For the June 2010 and March 2011 campaigns, points above the conservative mixing line (Fig. 4G) indicate a release of $\mathrm{Zn}$ from SPM at low salinity as previously reported for the Scheldt (Zwolsman et al., 1997) and Rhone (Elbaz-Poulichet et al., 1996) Estuaries. Such results contrast with the conservative behavior found in the Danube estuary (Guieu et al., 1998). For the other campaigns, no trend was clearly defined.

Co was mainly found in the dissolved fraction for all points: rivers, outlet and sea (Fig. 4J), contrary to what was observed, for instance, in the Hudson River Estuary or San Francisco Bay (TovarSánchez et al., 2004). Concentrations of dissolved Co in rivers were 2-3-fold higher than the world river average (Table 1). Dissolved Co increased at the outlet compared to the river values, which indicates an input of dissolved Co by the TWW. The dissolved Co decreased from $7.4 \mathrm{nM}$ on average at the outlet to $0.52 \mathrm{nM}$ at the marine end-member, this latter value being high when compared with the average of $0.078 \mathrm{nM}$ in surface western Mediterranean waters (Morley et al., 1997). Along the salinity gradient, the proportion of dissolved Co remained at approximately $80 \%$ of the total Co. Data from the June 2010 campaign were above the conservative mixing line; for the March 2011 campaign, samples were 

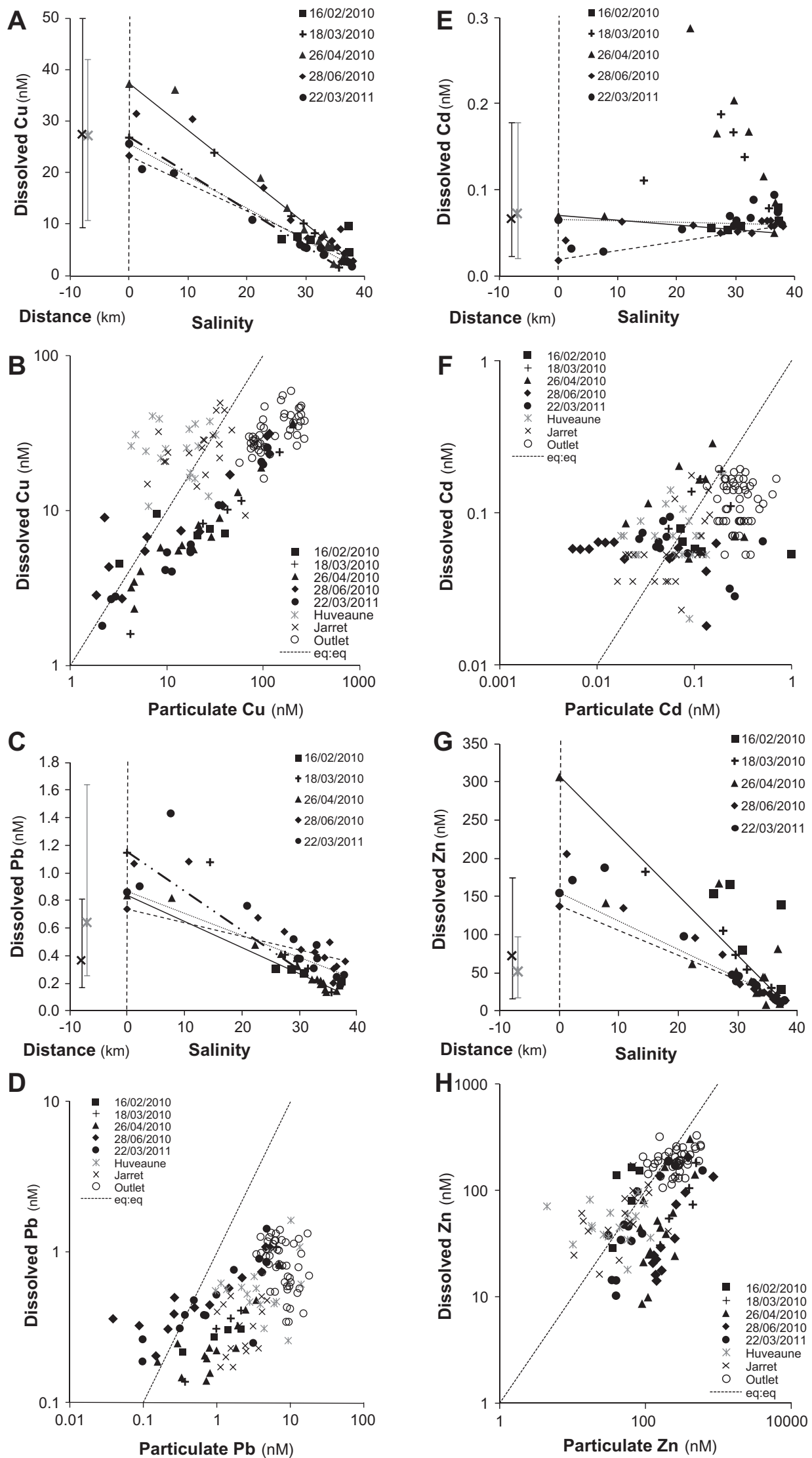

Fig. 4. Variation of dissolved metal in Huveaune $\left({ }^{*}\right)$ and in Jarret $(x)$ rivers, as a function of the distance until outlet, and from outlet to seawater, as a function of the salinity gradient for each sampling campaign for $\mathrm{Cu}(\mathrm{A}), \mathrm{Pb}(\mathrm{C}), \mathrm{Cd}(\mathrm{E}), \mathrm{Zn}(\mathrm{G}), \mathrm{Co}(\mathrm{I})$ and $\mathrm{Ni}(\mathrm{K})$; vertical lines at river points join maximum and minimum values. Variation of dissolved metal as a function of particulate metal for $\mathrm{Cu}(\mathrm{B}), \mathrm{Pb}(\mathrm{D}), \mathrm{Cd}(\mathrm{F}), \mathrm{Zn}(\mathrm{H}), \mathrm{Co}(\mathrm{J})$ and $\mathrm{Ni}(\mathrm{L})$; the dotted line (eq:eq) represents the same metal concentration in the dissolved and particulate phases. 

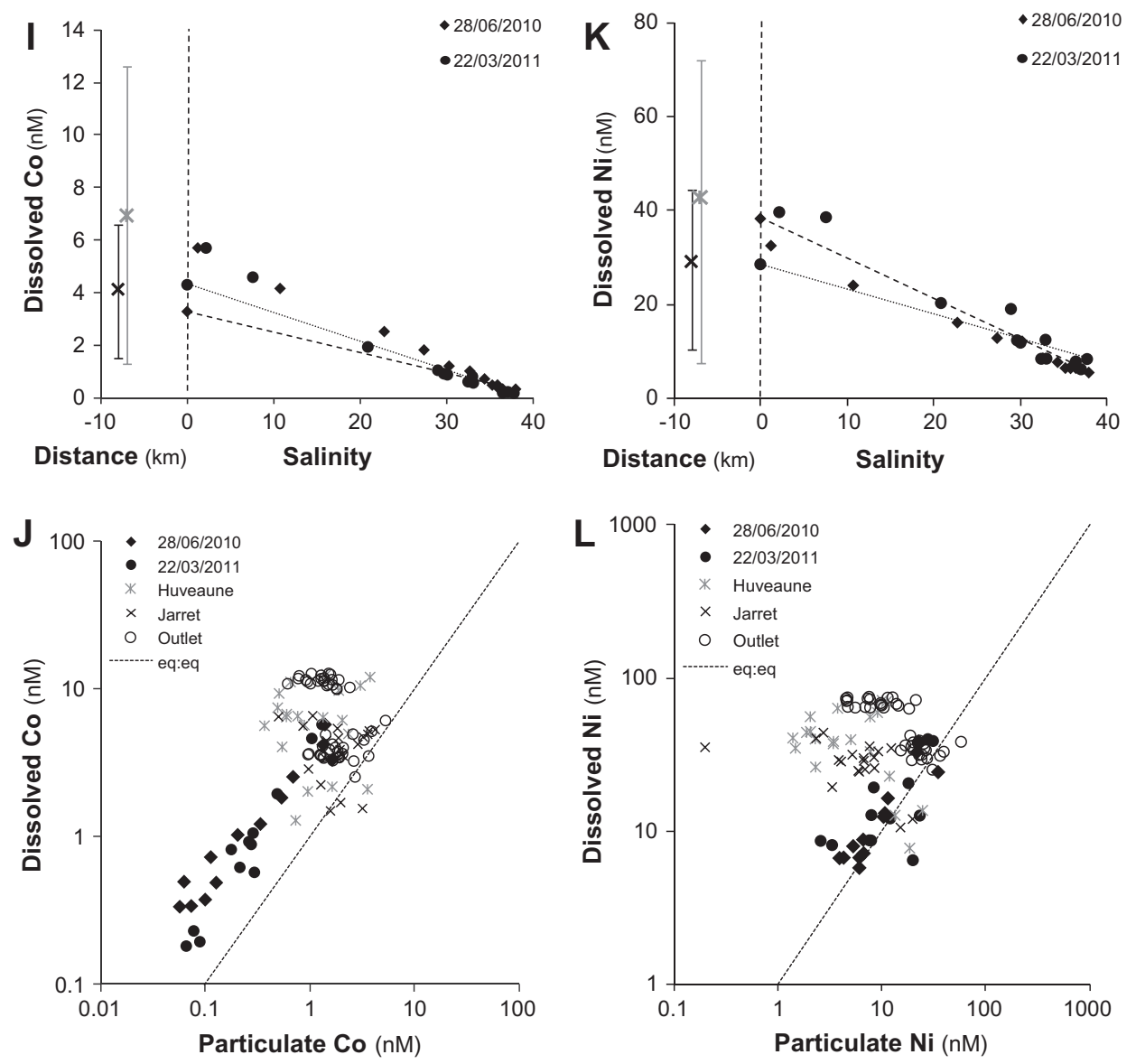

Fig. 4. (continued)

above the conservative mixing line until a salinity of 10 and along the conservative mixing line at higher salinities (Fig. 4I). This indicates a fast release of Co from the particles to the dissolved phase at the beginning of the plume. A non-conservative behavior was also observed for the Hudson River estuary, but there, the concentration of dissolved Co increased with increasing salinity. The main process responsible of this non-conservative behavior could be desorption from suspended particulates (Takata et al., 2010; Tovar-Sánchez et al., 2004).

Dissolved Ni was slightly higher in the Huveaune river than in the Jarret river and 2-3-fold higher than the world river average (Table 1). The TWW input brought both dissolved and particulate $\mathrm{Ni}$, but the higher particulate/dissolved $\mathrm{Ni}$ ratio at the outlet compared to the rivers indicates a higher particulate input by the TWW (Fig. 4L). Dissolved $\mathrm{Ni}$ decreased from $50 \mathrm{nM}$, on average, at the outlet to $8.4 \mathrm{nM}$ at the marine endmember, this latter value being high when compared to the $2.30 \mathrm{nM}$ value given for surface western Mediterranean waters by (Morley et al., 1997), but in the same range of concentration as in eastern Mediterranean waters $((2.22-18.5 \mathrm{nM})$ (Zeri and Voutsinou-Taliadouri, 2003)). The proportion of dissolved $\mathrm{Ni}$ within the total increased along the salinity gradient from $60 \%$ to $80 \%$. For the June 2010 campaign, the data points were below the theoretical mixing line, which signifies adsorption of $\mathrm{Ni}$ onto particles (Fig. 4K). For March 2011, the data points were above the theoretical mixing line, which implies a release of $\mathrm{Ni}$ into the dissolved phase. These behaviors differ from the conservative behavior observed in the Ob Estuary (Dai and Martin, 1995) and in the Rhône Estuary (Elbaz-Poulichet et al., 1996).

\subsection{Daily estimated fluxes and specific fluxes during the dry period}

Considering our data set of recorded carbon and metal levels, daily element fluxes during the dry period were estimated by dividing the average concentrations (Table 1 ) by the average flow (see Section 2.1) for each element studied in both the rivers and the outlet. Additionally, specific element fluxes were calculated by dividing the obtained element fluxes according to river watershed (see Section 2.1). For the outlet, the watershed was estimated as the sum of the Huveaune and Jarret watersheds, which then comprise the main part of Marseille city. To evaluate the TWW contribution to the global discharge to the coastal zone, the element flux ratio $(F)$ was calculated as the outlet flux divided by the sum of the river fluxes. The values obtained are summarized in Table 2 and compared to those calculated for the Eygoutier and the Rhone Rivers, used as examples of small and large coastal Mediterranean rivers, respectively. Concerning the Eygoutier, fluxes were calculated using the element concentrations reported by Nicolau et al. (2012) using the average flow during the dry period $\left(15 \mathrm{~L} \mathrm{~s}^{-1}\right)$. Concerning the Rhone, fluxes were estimated by averaging the measured concentrations (Ollivier et al., 2011) at low flow periods, i.e., below the Rhone average flow of $1600 \mathrm{~m}^{3} \mathrm{~s}^{-1}$. The results obtained for the rivers showed that the total specific fluxes of carbon and metals were higher for the Jarret than for the Huveaune, meaning that the watershed of the Jarret river is more contaminated compared with that of the Huveaune (Table 2). The total specific fluxes of the Eygoutier River were lower than those observed for the Huveaune and Jarret Rivers, which implied a higher level of contamination for the Huveaune and Jarret watersheds compared with that of the Eygoutier. In contrast, the total specific 


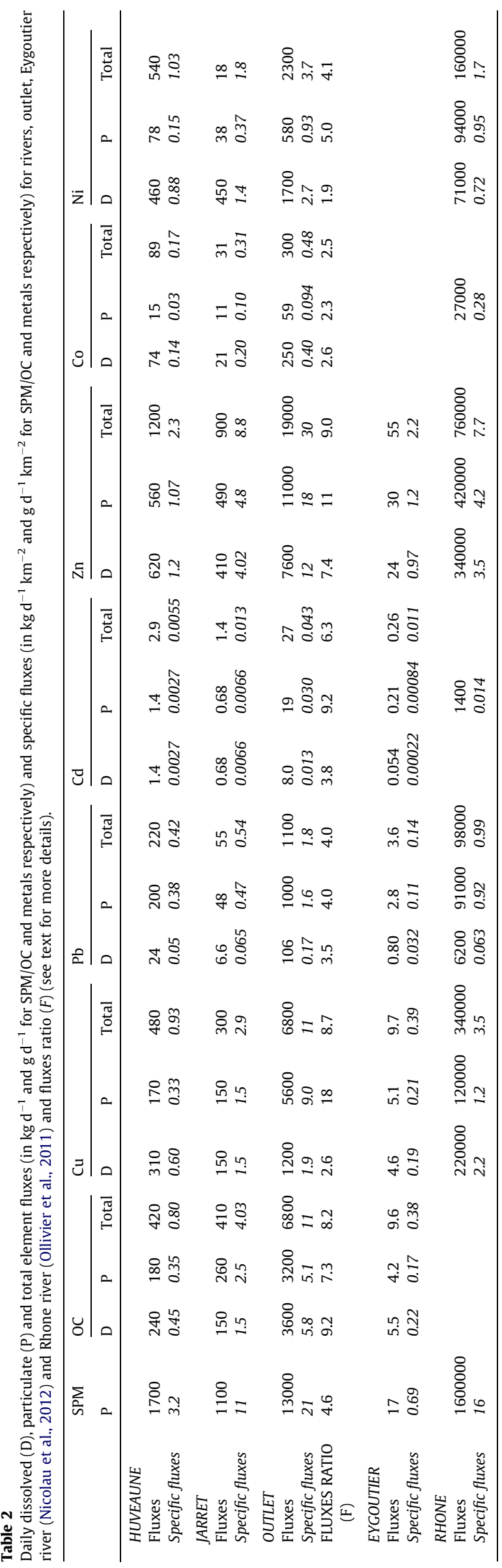

fluxes of the Rhone River were comparable to those of the Huveaune and Jarret Rivers, which indicates the same range of contamination for the three corresponding watersheds.

At the outlet, the carbon- and metal-specific fluxes were between 2- and 4-fold higher than the total specific fluxes of the rivers, which implies high carbon and metal inputs by the WWTP. For instance, the $\mathrm{Zn}$ daily flux was estimated as $19 \mathrm{~kg}$ (40\% as dissolved), which means approximately $5.7 \mathrm{t}$ of $\mathrm{Zn}$ were discharged each year in this coastal zone during the dry period (considering 300 days a year). This value appeared to be significantly higher than the "background input" estimated at $0.2 \mathrm{t}$ calculated using the upper continental crust $\mathrm{Zn}$ content of $52 \mu \mathrm{g} \mathrm{g}^{-1}$ (Wedepohl, 1995 ) and the SPM daily discharge (Table 2). The specific fluxes at the outlet were also between 2- and 4-fold higher than specific fluxes of the Rhone river. Moreover, the element flux ratio $(F)$ varied from 2 (for dissolved $\mathrm{Ni}$ ) to 18 (for particulate $\mathrm{Cu}$ ), which demonstrated the high impact of the WWTP on the river quality and, finally, on the coastal zone.

\subsection{Remobilization experiment}

Results from the remobilization experiment were compared to the measurements performed on samples from the 28 June 2010 campaign, allowing a direct comparison between real and batch mixing of the effluent with the seawater. DOC results showed conservative behavior with salinity (data not shown). Conversely, dissolved metal concentrations showed significant discrepancies with theoretical mixing lines (Fig. 5); these discrepancies were time-, element- and salinity-dependent.

Regarding $\mathrm{Cu}$, the field campaign results indicated a slight release of dissolved $\mathrm{Cu}$ from the SPM in the plume (Fig. 5A). The same behavior was observed during the batch experiment, but with a higher amplitude at low salinity $(<10)$, especially for the shorter mixing time. This indicates a fast release of $\mathrm{Cu}$ from SPM during the first minutes after mixing, up to $38 \%$ of the outlet particulate $\mathrm{Cu}$ content, followed by a progressive re-adsorption until reaching the field level at approximately $1 \mathrm{~h}$ after mixing. These results signify that the dissolved $\mathrm{Cu}$ measured from field samples at salinities below 10 was presumably under-estimated compared to the actual values because filtration was performed a few hours after sampling.

$\mathrm{Ni}$ had an opposite behavior to $\mathrm{Cu}$ in both the plume and the batch experiments, with a strong and fast adsorption (up to 55\% of the outlet dissolved $\mathrm{Ni}$ ) onto particles at low salinity, followed by increasing desorption with mixing time (Fig. 5B). This behavior was, however, most pronounced during the first minutes after mixing, the field campaign values being reached at approximately $1 \mathrm{~h}$ after mixing. Therefore, in contrast to $\mathrm{Cu}$, dissolved Ni measurements from the field samples at salinities below 10 were presumably over-estimated compared to the actual values.

Regarding Cd, both the field and batch values indicated strong release from particles to the dissolved phase, but in contrast to $\mathrm{Cu}$, the dissolved $\mathrm{Cd}$ concentrations continuously increased with the mixing time (Fig. 5C). The maximum, close to $0.15 \mathrm{nM}$, was observed at the lowest salinity $(S=1)$ after $6 \mathrm{~h}$ of mixing and corresponded to desorption of $\sim 100 \%$ of the particulate Cd. Finally, as observed for $\mathrm{Cu}$ and $\mathrm{Ni}$, the field points were in the same range of concentration as the $1 \mathrm{~h}$-mixing batch points.

$\mathrm{Co}, \mathrm{Pb}$ and $\mathrm{Zn}$ (data not shown) presented non-conservative behaviors in both the plume and the batch experiments, with maximal desorptions at the lowest salinity for $\mathrm{Co}$ and $\mathrm{Pb}$ and at salinity 10 for Zn. No clear trend was observed with the mixing time. For these three metals, the field points showed similar values to the 15 min-mixing batch points.

Finally, this remobilization experiment showed that release of at least $\mathrm{Cu}$ in the salinity gradient is achieved with fast kinetics, 

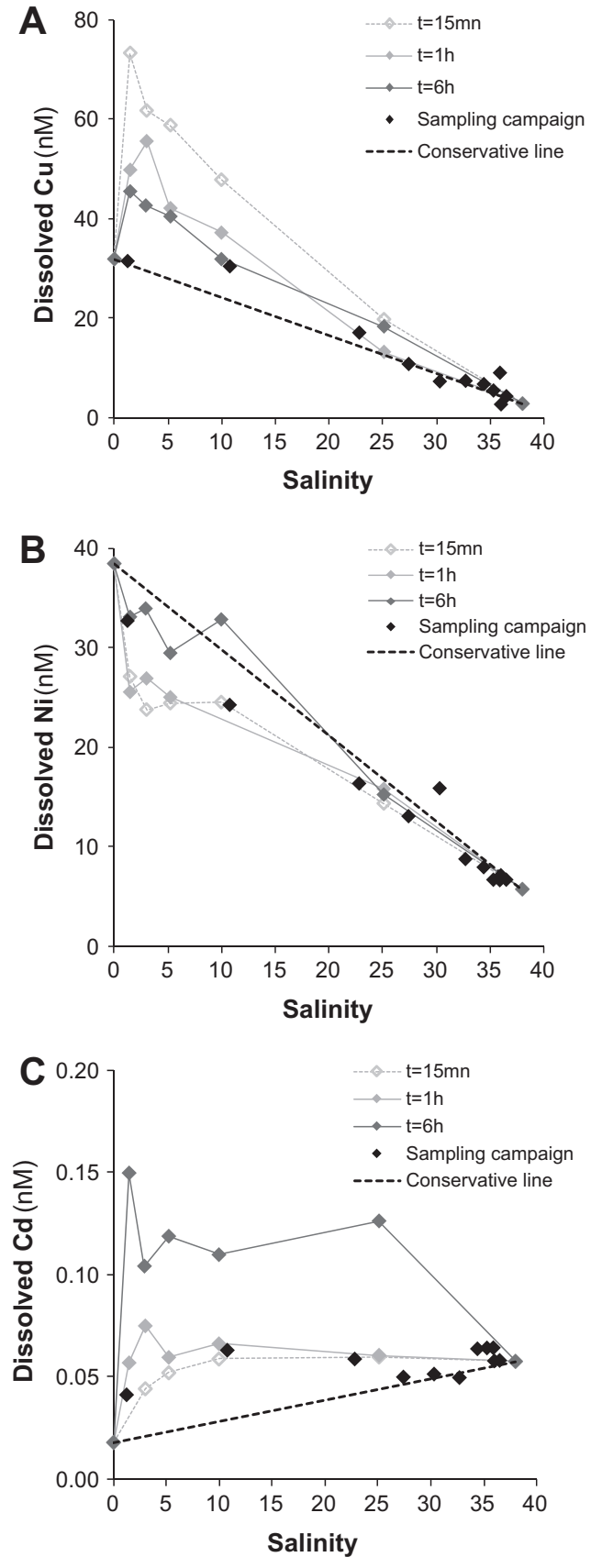

Fig. 5. Dissolved $\mathrm{Cu}(\mathrm{A}), \mathrm{Ni}(\mathrm{B})$ and $\mathrm{Cd}(\mathrm{C})$ as a function of salinity after different mixing time during the remobilization experiment and comparison with field level.

which raises questions about sample stability between sampling and filtration in the laboratory.

\subsection{Comparison between on-board and in-laboratory filtration}

Concentrations of dissolved $\mathrm{Cu}$ and $\mathrm{Ni}$ using the two protocols for filtration (see Sections 2.2 and 2.3) are given in Fig. 6.

Regarding dissolved $\mathrm{Cu}$, the on-board filtration gave much higher values than did the laboratory filtration (Fig. 6A). Moreover, while the laboratory filtration suggested a conservative trend, the on-board filtration revealed (1) a 2.6-fold higher dissolved $\mathrm{Cu}$ concentration at the outlet and (2) a significant additional $\mathrm{Cu}$ desorption from the SPM at low salinities, as was observed during the remobilization experiment. Similar results were observed for $\mathrm{Pb}$,
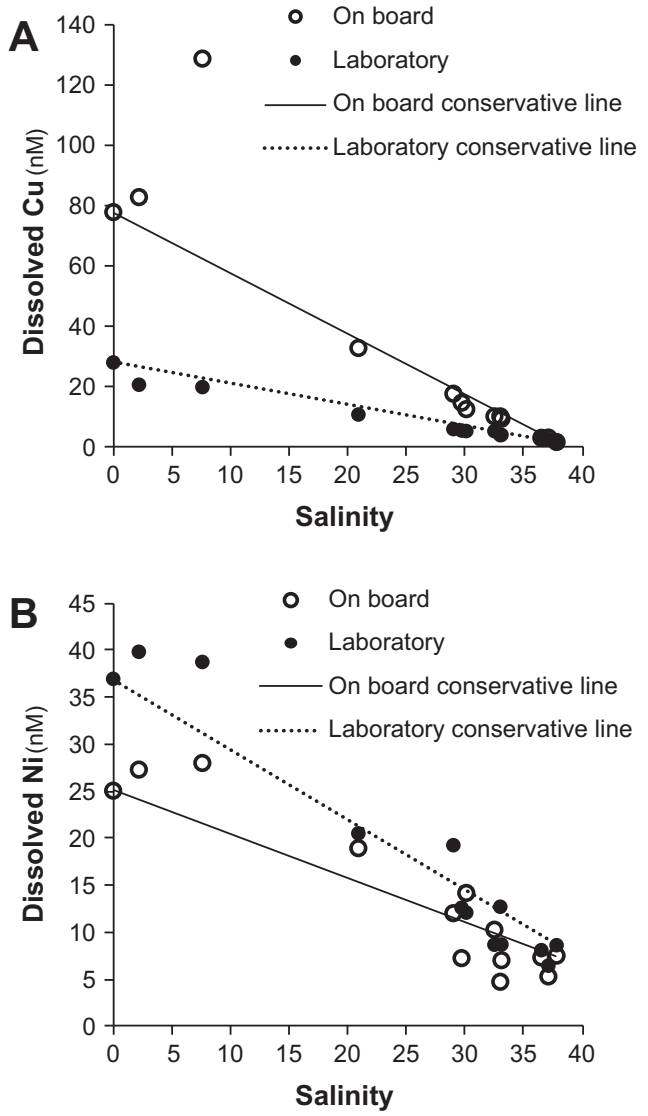

Fig. 6. Comparison between on board (open circles) and laboratory (full circles) filtrations for dissolved $\mathrm{Cu}$ (A) and $\mathrm{Ni}$ (B) as a function of salinity for the 22/03/2011 sampling.

Zn and Cd. Regarding dissolved $\mathrm{Co}$ and $\mathrm{Ni}$, the on-board filtration gave lower values than did the laboratory filtration (Fig. 6B). Both protocols revealed metal desorption from the SPM at low salinity, followed by re-adsorption at salinities higher than 25 . Concerning DOC (data not shown), no significant difference was observed between the on-board and in-laboratory filtrations, which means that the dissolved/particulate organic carbon fractionation was at equilibrium.

These results are consistent with the remobilization experiment and show that, at the outlet, the mixing of the river water with the TWW was not at equilibrium and that fast desorption/adsorption kinetics in the plume necessitates rapid processing of the samples. Moreover, these results suggest that the dissolved fraction of the metal fluxes from the outlet was most likely significantly underestimated, except for Cd.

\subsection{Identification of an abnormal event}

The 18/04/2012 campaign showed unexpectedly high SPM, DOC, POC and metal concentrations compared with the previous ones. The DOC in the rivers was similar to that observed during the other campaigns $\left(1.3 \mathrm{mg} \mathrm{CL}^{-1}\right.$ for the Huveaune and $2.3 \mathrm{mg} \mathrm{C} \mathrm{L}^{-1}$ for the Jarret), but at the outlet, the DOC was approximately 30 and $55 \mathrm{mg} \mathrm{C} \mathrm{L}^{-1}$ using laboratory and on-board filtration, respectively (Fig. 7), these values being, respectively, 5and 9-fold higher than the average value at the outlet (Table 1). The difference between the laboratory and on-board filtration values indicates that the outlet sample was not at equilibrium at the sampling moment. In the salinity gradient and for both filtrations, data points were below the conservative mixing lines, 


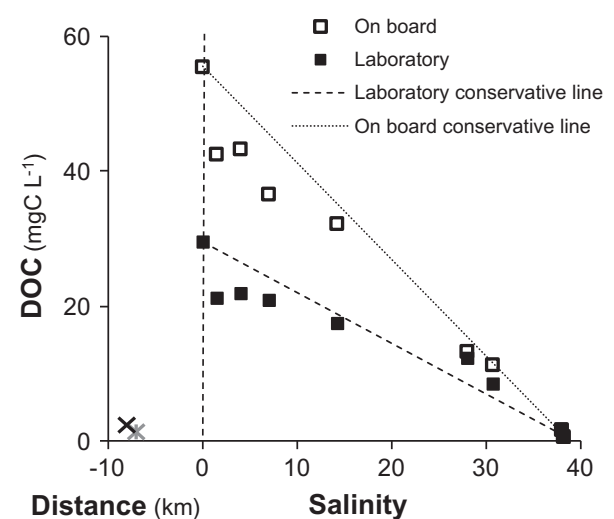

Fig. 7. Comparison between on board (open square) and laboratory (full square) filtrations for DOC as a function of salinity for the 18/04/2012 sampling.

indicating a transfer from the dissolved to the particulate fraction, most likely corresponding to OM agglomeration/flocculation processes.

Dissolved metals at the outlet were in the same range of concentration as was found during the other campaigns after laboratory filtration, but were 2-fold higher than the 22/03/ 2011 campaign after on-board filtration. The behavior of the dissolved metals in the plume was the same as during other campaigns.

The higher DOC and metal values observed at the outlet during this event was likely due to a malfunction of the WWTP or a bypass of the WWTP. Even if the occurrence of such phenomena is likely infrequent, their local impact on the coastal zone is most likely not negligible.

3.6. One-day outlet monitoring: impact of the TWW on the elements discharged to the coastal zone

Interpretation of results obtained from the outlet effluent day monitoring (see Section 2.5) will allow evaluation of hourly changes in the TWW and quantification of the TWW's overall impact on elements discharged to the coastal zone. The results obtained for dissolved $\mathrm{Pb}$ and DOC are plotted in Fig. 8 .

The river flows during the sampling day remained roughly constant ( $\sim 3.5$ and $1 \mathrm{~m}^{3} \mathrm{~s}^{-1}$ for the Huveaune and Jarret, respectively), therefore the observed flow variation at the outlet can be attributed mostly to TWW input fluctuation. The average daily flow at the outlet was $6.4 \mathrm{~m}^{3} \mathrm{~s}^{-1} ; 2$ minima $\left(4.9 \mathrm{~m}^{3} \mathrm{~s}^{-1}\right.$ at $6: 30 \mathrm{am}$ and $5.4 \mathrm{~m}^{3} \mathrm{~s}^{-1}$ at $\left.5: 30 \mathrm{pm}\right)$ and 2 maxima $\left(9 \mathrm{~m}^{3} \mathrm{~s}^{-1}\right.$ at $10: 00 \mathrm{pm}$ and $9.5 \mathrm{~m}^{3} \mathrm{~s}^{-1}$ at $11: 15 \mathrm{am}$ ) were observed. During the night, the flow decreased due to the diminution of wastewater brought to the WWTP. From 6:30 to 11:15 am, the flow increased due to the increase of anthropogenic inputs to the WWTP. It should be noted that the wastewater residence time in the WWTP being $1 \mathrm{~h}$, the TWW flow peaks correspond roughly to wastewater input peaks that occurred $1 \mathrm{~h}$ before.

The contribution (in\%) of the rivers and the TWW to the outlet water was calculated for the whole sampling day period for each element or compound $(X)$ using the 4 following equations, where $Q_{\text {Huv }}, Q_{\text {Jar }}, Q_{\text {out }}$ and $Q_{w w T P}$ are the fluxes of the Huveaune River, the Jarret River, at the outlet and from the WWTP, respectively, and $[X]_{H u v},[X]_{J a r},[X]_{\text {Out }}$ and $[X]_{\text {WWTP }}$ are the corresponding concentrations of the given element or compound.

$Q_{\text {out }}^{i}=Q_{W W T P}^{i}+\bar{Q}_{H u v}+\bar{Q}_{J a r}$

$Q_{\text {out }}^{i} \times[X]_{\text {out }}^{i}=Q_{W W T P}^{i} \times[X]_{W W T P}^{i}+\bar{Q}_{H u v} \times[\bar{X}]_{\text {Huv }}+\bar{Q}_{J a r} \times[\bar{X}]_{J a r}$

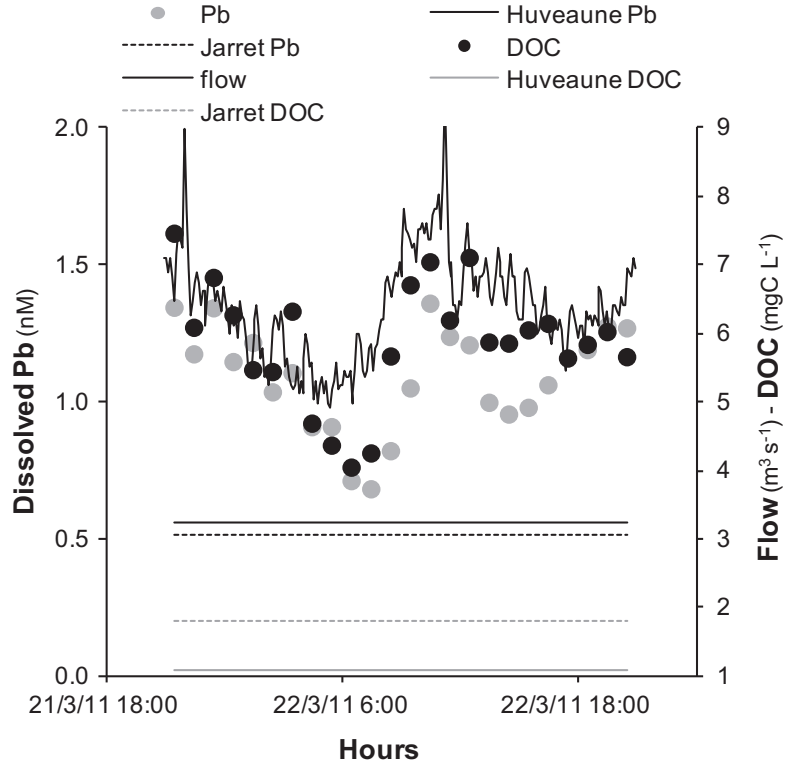

Fig. 8. Variations of dissolved $\mathrm{Pb}$ and $\mathrm{DOC}$ concentrations and flow as a function of time.

$\% X_{\text {river }}=\left(\frac{\bar{Q}_{H u v} \times[\bar{X}]_{H u v}+\bar{Q}_{\text {Jar }} \times[\bar{X}]_{\text {Jar }}}{\left(\sum_{24}^{i=1} Q_{\text {out }}^{i} \times[X]_{\text {out }}^{i}\right) / 24}\right) \times 100$

$\% X_{W W T P}=\left(\frac{\left(\sum_{24}^{i=1} Q_{W W T P}^{i} \times[X]_{W W T P}^{i} / 24\right)}{\left(\sum_{24}^{i=1} Q_{\text {out }}^{i} \times[X]_{\text {out }}^{i} / 24\right)}\right) \times 100=100-\% X_{\text {river }}$

TWW temporal flow ( $Q_{W W T P}^{i}$ ) was calculated using Eq. (1). Resolution of Eq. (2) for each dissolved/particulate element studied (organic/inorganic carbon, major ions and trace elements) enabled the calculation of their temporal concentrations $\left([X]_{\text {WWTP }}^{i}\right)$ in the TWW. Eq.3 and Eq.4 enabled evaluation of the respective contributions of the rivers vs. the WWTP to the outlet. The results obtained, ranked by increasing contributions of the rivers, are depicted in Fig. 9.

In the rivers, dissolved $\mathrm{Pb}$ was approximately $0.5 \mathrm{nM}$, whereas at the outlet, it varied from 0.7 to $2 \mathrm{nM}(1.13 \mathrm{nM}$ on average) during the day. The variation in dissolved $\mathrm{Pb}$ at the outlet followed the variation of the outlet flow, which indicates that the dissolved $\mathrm{Pb}$ at the outlet was significantly influenced by the TWW input. The dissolved $\mathrm{Pb}$ in the TWW was calculated from the flows and concentrations in the rivers and at the outlet, and it varied from 1.3 to $7.4 \mathrm{nM}$ ( $3 \mathrm{nM}$ on average) during the sampling day.

In the Huveaune and Jarret Rivers, the DOC was approximately 1 and $1.8 \mathrm{mg} \mathrm{C} \mathrm{L}^{-1}$, respectively. At the outlet, it varied from 4 to $7.5 \mathrm{mg} \mathrm{C} \mathrm{L}^{-1}$ (5.9 $\mathrm{mg} \mathrm{C} \mathrm{L}^{-1}$ on average). Therefore, as was observed for the dissolved $\mathrm{Pb}$, the DOC at the outlet was mainly controlled by the TWW inputs. Calculated DOC in the TWW varied from 15 to $40 \mathrm{mg} \mathrm{C} \mathrm{L}^{-1}, 21 \mathrm{mg} \mathrm{C} \mathrm{L}^{-1}$ on average.

The contribution of the rivers was higher for dissolved $\mathrm{Mg}^{2+}$, $\mathrm{Ca}^{2+}, \mathrm{SO}_{4}^{2-}, \mathrm{F}^{-}$and DIC; these species are characteristic of karstic systems and are naturally present in river systems (Nicolau et al., 2012). In contrast, the contribution of the WWTP was higher for most of the dissolved and particulate metals, TOC, $\mathrm{N}$ species and SPM. For instance, WWTP is responsible for more than $90 \%$ of the particulate $\mathrm{Cd}, \mathrm{Pb}$ and $\mathrm{Cu}$ inputs to the coastal zone. The presence 


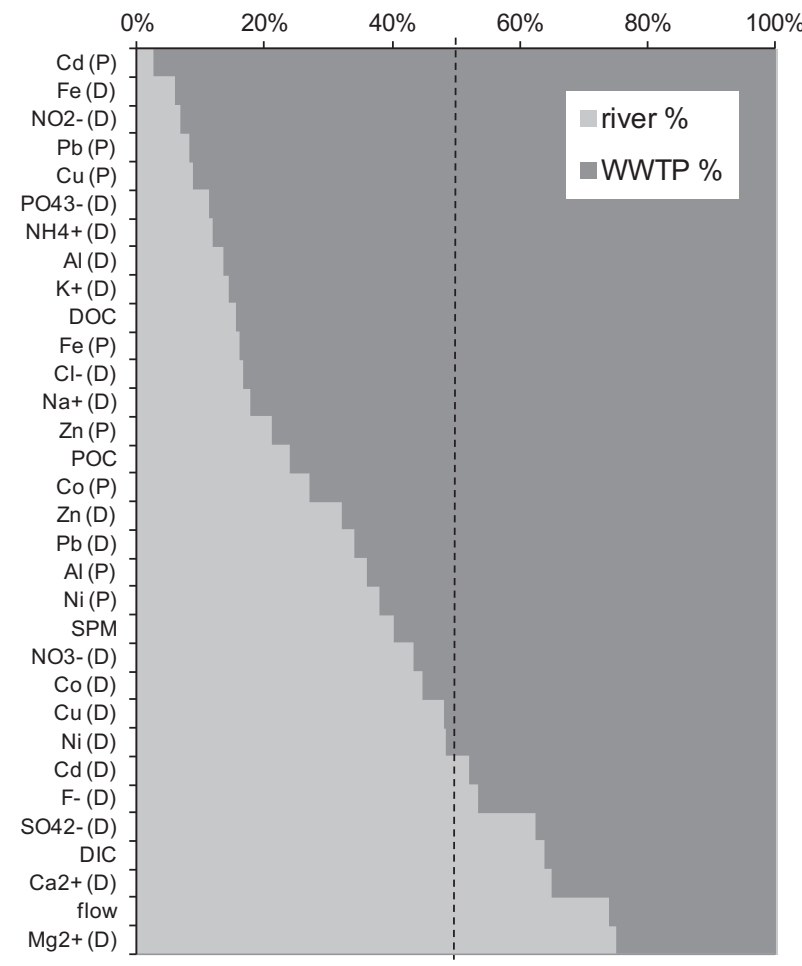

Fig. 9. Contribution of river vs. WWTP at the outlet. The dotted line represents equal contribution of rivers and WWTP; the letter in brackets indicates particulate (P) or dissolved (D) fraction.

of reduced $\mathrm{N}$ forms $\left(\mathrm{NO}_{2}^{-}, \mathrm{NH}_{4}^{+}\right)$in the outlet water is also a clear signature of bacterial degradation of the WWTP organic matter inputs, and confirms the dissolved $\mathrm{O}_{2}$ consumption previously observed (see Section 3.1.1). In summary, river signatures at the outlet were hidden by anthropogenic inputs for most elements and compounds, which demonstrates the influence of TWW inputs to the coastal zone despite physical/biological treatments used in the WWTP. Some elements could be used as tracers (ex: $\mathrm{K}^{+}, \mathrm{Na}^{+}$, $\mathrm{Cl}^{-}$) to quantify the influence of TWW in outlet waters.

\section{Concluding remarks}

Most studies dedicated to Mediterranean river inputs to the sea have focused on flood events because storm flows in such areas are responsible for most of the annual inputs to the sea of SPM, organic matter and potentially toxic metal. Herein, the dynamic of contaminants during dry periods (which represent more than 300 days per year in such systems) was investigated, during which slow chronic contamination can occur in the plume of a Mediterranean stratified urban estuary receiving effluents from a large sewage treatment plant (Marseille agglomeration).

Dissolved and total organic carbon and metal concentrations in the rivers considered were comparable to values observed for other small coastal Mediterranean rivers, surpassing the world average river values. Concerning the trace metal dynamics in the plume salinity gradient, $\mathrm{Cu}, \mathrm{Cd}, \mathrm{Co}, \mathrm{Pb}$ and $\mathrm{Zn}$ are desorbed from the SPM, increasing the potentially bioavailable fraction of these metals. This study has clearly demonstrated that the release of metal ions can occur at low salinity with fast kinetics followed by partial re-adsorption onto SPM; this behavior was especially observed for $\mathrm{Cu}$. Other metals, such as $\mathrm{Ni}$, can undergo a fast adsorption onto SPM followed by slower desorption. Such unusual behaviors make mandatory the practice of filtration immediately after sampling to avoid under- or over-estimation of dissolved metal concentrations.
The second important point of this study is that, at the outlet, the river signatures were hidden by the WWTP anthropogenic input for most elements or compounds. The anthropogenic input was higher than $90 \%$ of the total input to the sea for particulate $\mathrm{Cd}, \mathrm{Pb}$ and $\mathrm{Cu}$ and higher than $65 \%$ for particulate $\mathrm{Zn}$, Co and dissolved $\mathrm{Zn}$ and $\mathrm{Pb}$. The daily variation of these inputs followed the fluctuations of the TWW issued from WWTP. Although most likely not frequent, the observed abnormal event linked to a WWTP malfunction or by-pass can temporally strongly enhance the impact of an urbanized area on the coastal zone. Similar phenomena all around the Mediterranean are more than probable, especially in countries without wastewater treatment plants. This underlines the need for such treatment facilities for an improvement of local coastal water quality, but most likely also at a more global scale. Such chronic fluxes of pollutants require better study in comparison to other main sources (large rivers, aerosols, etc.). Considering the high anthropogenic organic matter and trace element contents of the output to the sea, a detailed study of their chemical speciations, which are known to be strongly influenced by dissolved organic ligands, must be performed to evaluate their bioavailability for marine biota.

\section{Acknowledgments}

The authors would like to thank everyone who participated in the sampling campaigns for their help with sample preparation, particularly Dr. C. Le Poupon for major ion analyses. The authors would also like to thank "IFREMER" (Dr. M. Zebracki, Dr. D. Cossa, Dr. I. Pairaud), "Météo France" (Y. Bidet), "SERAM" (A. Queau), and "DEA" of Marseille city (Z. Djelalli) for access to the study site, material installation and flow values.

This collaborative work and B. Oursel, Ph.D., were financially supported by the "ANR CES MARSECO" and the "GIRAC-PACA" (FUI, TPM, Région PACA); this study was part of the "MerMexWP3-C3A" and international "IMBER" projects.

\section{Appendix A. Supplementary material}

Supplementary data associated with this article can be found, in the online version, at http://dx.doi.org/10.1016/j.marpolbul.2013. 01.023 .

\section{References}

Álvarez-Salgado, X.A., Miller, A.E.J., 1998. Dissolved organic carbon in a large Macrotidal Estuary (the Humber, UK): behaviour during estuarine mixing. Mar. Pollut. Bull. 37, 216-224.

Ammann, A.A., Rüttimann, T.B., Bürgi, F., 2000. Simultaneous determination of TOC and TNb in surface and wastewater by optimised high temperature catalytic combustion. Water Res. 34, 3573-3579.

Bay, S.M., Zeng E.Y. Lorenson, T.D. Tran, K., Alexander, C. 2003. Temporal and spatial distributions of contaminants in sediments of Santa Monica Bay California. Mar. Environ. Res. 56, 255-276.

Bothner, M.H., Casso, M.A., Rendigs, R.R., Lamothe, P.J., 2002. The effect of the new Massachusetts Bay sewage outfall on the concentrations of metals and bacterial spores in nearby bottom and suspended sediments. Mar. Pollut. Bull. 44, 10631070.

Bruland, K.W., Lohan, M.C., 2003. Controls of Trace Metals in Seawater. In: Heinrich, D.H., Karl, K.T. (Eds.), Treatise on Geochemistry. Pergamon, Oxford, pp. 23-47 (02.06.03).

Busetti, F, Badoer, S., Cuomo, M., Rubino, B., Traverso, P., 2005. Occurrence and removal of potentially toxic metals and heavy metals in the wastewater treatment plant of Fusina (Venice, Italy). Ind. Eng. Chem. Res. 44, 9264-9272.

Buzier, R., Tusseau-Vuillemin, M.-H., Keirsbulck, M., Mouchel, J.-M., 2011. Inputs of total and labile trace metals from wastewater treatment plants effluents to the Seine River. Phys. Chem. Earth 36, 500-505.

Cai, Y., Guo, L., Wang, X., Mojzis, A.K., Redalje, D.G., 2012. The source and distribution of dissolved and particulate organic matter in the Bay of St Louis, northern Gulf of Mexico. Estuar. Coast. Shelf Sci. 96, 96-104.

Callahan, J., Dai, M., Chen, R.F., Li, X., Lu, Z., Huang, W., 2004. Distribution of dissolved organic matter in the Pearl River Estuary, China. Mar. Chem. 89, 211 224. 
Cauwet, G., Miller, A., Brasse, S., Fengler, G., Mantoura, R.F.C., Spitzy, A., 1997. Dissolved and particulate organic carbon in the western Mediterranean Sea. Deep-Sea Res. Part II 44, 769-779.

Chronis, G., Lykousis, V., Georgopoulos, D., Zervakis, V., Stavrakakis, S., Poulos, S., 2000. Suspended particulate matter and nepheloid layers over the southern margin of the Cretan Sea (N.E. Mediterranean): seasonal distribution and dynamics. Prog. Oceanogr. 46, 163-185.

Dai, M.-H., Martin, J.-M., 1995. First data on trace metal level and behaviour in two major Arctic river-estuarine systems ( $\mathrm{Ob}$ and Yenisey) and in the adjacent Kara Sea, Russia. Earth Planet Sci. Lett. 131, 127-141.

Dai, M., Martin, J.-M., Cauwet, G., 1995. The significant role of colloids in the transport and transformation of organic carbon and associated trace metals $(\mathrm{Cd}$, $\mathrm{Cu}$ and $\mathrm{Ni}$ ) in the Rhône delta (France). Mar. Chem. 51, 159-175.

Dassenakis, M., Scoullos, M., Gaitis, A., 1997. Trace metals transport and behaviour in the Mediterranean estuary of Acheloos river. Mar. Pollut. Bull. $34,103-111$.

Di Leonardo, R., Vizzini, S., Bellanca, A., Mazzola, A., 2009. Sedimentary record of anthropogenic contaminants (trace metals and PAHs) and organic matter in a Mediterranean coastal area (Gulf of Palermo, Italy). J. Marine Syst. 78, 136-145.

Drewes, J.E., Jekel, M., 1998. Behavior of DOC and AOX using advanced treated wastewater for groundwater recharge. Wat. Res. 32, 3125-3133.

Elbaz-Poulichet, F., Martin, J.-M., 1987. Dissolved Cd behaviour in some selected French and Chinese estuaries. Consequences on Cd supply to the ocean. Mar. Chem. 22, 125-136.

Elbaz-Poulichet, F., Guan, D.M., Martin, J.-M., 1991. Trace metal behaviour in a highly stratified Mediterranean estuary: the Krka (Yugoslavia). Mar. Chem. 32, 211-224.

Elbaz-Poulichet, F., Garnier, J.-M., Guan, D.M., Martin, J.-M., Thomas, A.J., 1996. The conservative behaviour of trace metals $(\mathrm{Cd}, \mathrm{Cu}, \mathrm{Ni}$ and $\mathrm{Pb})$ and as in the surface plume of stratified estuaries: example of the Rh ône River (France). Estuar. Coast. Shelf Sci. 42, 289-310.

Elbaz-Poulichet, F., 2005. River inputs of metals and Arsenic. In: Part, K., Alain Saliot (Eds.), The Mediterranean Sea, Series: The Handbook of Environmental Chemistry, vol. 5. Springer Verlag, Berlin Heidelberg, pp. 211-235.

Gaillardet, J., Viers, J., Dupré, B., 2003. Trace elements in River waters. In: Heinrich, D.H., Karl, K.T. (Eds.), Treatise on Geochemistry. Pergamon, Oxford, pp. 225-272 (09.05.03)

Gonzalez, H., Pomares, M., Ramirez, M., Torres, I., 1999. Heavy metals in organisms and sediments from the discharge zone of the submarine sewage outfall of Havana City, Cuba. Mar. Pollut. Bull. 38, 1048-1051.

Guieu, C., Martin, J.M., Tankéré, S.P.C., Mousty, F., Trincherini, P., Bazot, M., Dai, M.H., 1998. On trace metal geochemistry in the Danube River and Western Black Sea. Estuar. Coast. Shelf Sci. 47, 471-485.

Guo, L., White, D.M., Xu, C., Santschi, P.H., 2009. Chemical and isotopic composition of high-molecular-weight dissolved organic matter from the Mississippi River plume. Mar. Chem. 114, 63-71.

Jean, N., Dumont, E., Durrieu, G., Balliau, T., Jamet, J.-L., Personnic, S., Garnier, C., 2012. Protein expression from zooplankton communities in a metal contaminated NW mediterranean coastal ecosystem. Mar. Environ. Res. 80, $12-26$.

Kraepiel, A.M.L., Chiffoleau, J.-F., Martin, J.-M., Morel, F.M.M., 1997. Geochemistry of trace metals in the Gironde estuary. Geochim. Cosmochim. Acta 61, 1421-1436.

Lenoble, V., Omanović, D., Garnier, C., Mounier, S., Đonlagić, N., Le Poupon, C., Pižeta, I., 2013. Distribution and chemical speciation of arsenic and heavy metals in highly contaminated waters used for health care purposes (Srebrenica, Bosnia and Herzegovina). Sci. Total Environ. 443, 420-428.

Lorrain, A., Savoye, N., Chauvaud, L., Paulet, Y.-M., Naulet, N., 2003. Decarbonation and preservation method for the analysis of organic $\mathrm{C}$ and $\mathrm{N}$ contents and stable isotope ratios of low-carbonated suspended particulate material. Anal. Chim. Acta 491, 125-133.

Louis, Y., Garnier, C., Lenoble, V., Mounier, S., Cukrov, N., Omanovic, D., Pizeta, I., 2009. Kinetic and equilibrium studies of copper-dissolved organic matter complexation in water column of the stratified Krka River estuary (Croatia). Mar. Chem. 114, 110-119.

Martínez-Casasnovas, J.A., Ramos, M.C., Ribes-Dasi, M., 2002. Soil erosion caused by extreme rainfall events: mapping and quantification in agricultural plots from very detailed digital elevation models. Geoderma 105, 125-140.

Matthai, C., Birch, G.F., Bickford, G.P., 2002. Anthropogenic trace metals in sediment and settling particulate matter on a high-energy continental shelf (Sydney, Australia). Mar. Environ. Res. 54, 99-127.

Morley, N.H., Burton, J.D., Tankere, S.P.C., Martin, J.M., 1997. Distribution and behaviour of some dissolved trace metals in the western Mediterranean Sea. Deep-Sea Res. Part II 44, 675-691.
Morris, A.W., Mantoura, R.F.C., Bale, A.J., Howland, R.J.M., 1978. Very low salinity regions of estuaries: important sites for chemical and biological reactions. Nature 274, 678-680.

Nicolau, R., Lucas, Y., Merdy, P., Raynaud, M., 2012. Base flow and stormwater net fluxes of carbon and trace metals to the Mediterranean sea by an urbanized small river. Water Res. 46, 6625-6637.

Ollivier, P., Radakovitch, O., Hamelin, B., 2011. Major and trace element partition and fluxes in the Rhône River. Chem. Geol. 285, 15-31.

Omanović, D., Kwokal, Z., Goodwin, A., Lawrence, A., Banks, C.E., Compton, R.G., Komorsky-Lovrić, Š., 2006. Trace metal detection in Šibenik Bay, Croatia: cadmium, lead and copper with anodic stripping voltammetry and manganese via sonoelectrochemistry. A Case Study. J. Iran Chem. Soc. 3, 128-139.

Pernet-coudrier, B., Clouzot, L., Varrault, G., Tusseau-Vuillemin, M.-H., Verger, A., Mouchel, J.-M., 2008. Dissolved organic matter from treated effluent of a major wastewater treatment plant: characterization and influence on copper toxicity. Chemosphere 73, 593-599.

Rocha, L., Rodrigues, S.M., Lopes, I., Soares, A.M.V.M., Duarte, A.C., Pereira, E., 2011. The water-soluble fraction of potentially toxic elements in contaminated soils: relationships between ecotoxicity, solubility and geochemical reactivity. Chemosphere 84, 1495-1505.

Roux, L.L., Roux, S.L., Appriou, P., 1998. Behaviour and speciation of metallic species $\mathrm{Cu}, \mathrm{Cd}, \mathrm{Mn}$ and Fe during estuarine mixing. Mar. Pollut. Bull. 36, 56-64.

Saliot, A., Parrish, C.C., Sadouni, N.m., Bouloubassi, I., Fillaux, J., Cauwet, G., 2002. Transport and fate of Danube Delta terrestrial organic matter in the Northwest Black Sea mixing zone. Mar. Chem. 79, 243-259.

Sañudo-Wilhelmy, S.A., Rivera-Duarte, I., Russell Flegal, A., 1996. Distribution of colloidal trace metals in the San Francisco Bay estuary. Geochim. Cosmochim. Acta 60, 4933-4944.

Savoye, N., David, V., Morisseau, F., Etcheber, H., Abril, G., Billy, I., Charlier, K., Oggian, G., Derriennic, H., Sautour, B., 2012. Origin and composition of particulate organic matter in a macrotidal turbid estuary: the Gironde Estuary, France. Estuar. Coast. Shelf Sci.. http://dx.doi.org/10.1016/ j.ecss.2011.12.005.

Takata, H., Aono, T., Tagami, K., Uchida, S., 2010. Processes controlling cobalt distribution in two temperate estuaries, Sagami Bay and Wakasa Bay, Japan. Estuar. Coast. Shelf Sci. 89, 294-305.

Tessier, E., Garnier, C., Mullot, J.-U., Lenoble, V., Arnaud, M., Raynaud, M., Mounier, S., 2011. Study of the spatial and historical distribution of sediment inorganic contamination in the Toulon bay (France). Mar. Pollut. Bull. 62, 2075-2086.

Tovar-Sánchez, A., Sañudo-Wilhelmy, S.A., Flegal, A.R., 2004. Temporal and spatial variations in the biogeochemical cycling of cobalt in two urban estuaries: Hudson River Estuary and San Francisco Bay. Estuar. Coast. Shelf Sci. 60, 717728 .

Vega, M., van den Berg, C.M.G., 1997. Determination of cobalt in seawater by catalytic adsorptive cathodic stripping voltammetry. Anal. Chem. 69, 874-881.

Waeles, M., Riso, R.D., Maguer, J.-F., Le Corre, P., 2004. Distribution and chemical speciation of dissolved cadmium and copper in the Loire estuary and North Biscay continental shelf, France. Estuar. Coast. Shelf Sci. 59, 49-57.

Waeles, M., Tanguy, V., Lespes, G., Riso, R.D., 2008. Behaviour of colloidal trace metals $(\mathrm{Cu}, \mathrm{Pb}$ and $\mathrm{Cd})$ in estuarine waters: an approach using frontal ultrafiltration (UF) and stripping chronopotentiometric methods (SCP). Estuar. Coast. Shelf Sci. 80, 538-544.

Waeles, M., Riso, R.D., Cabon, J.-Y., Maguer, J.-F., L'Helguen, S., 2009. Speciation of dissolved copper and cadmium in the Loire estuary and over the North Biscay continental shelf in spring. Estuar. Coast. Shelf Sci. 84, 139-146.

Wang, Z.-L., Liu, C.-Q., 2003. Distribution and partition behavior of heavy metals between dissolved and acid-soluble fractions along a salinity gradient in the Changjiang Estuary, eastern China. Chem. Geol. 202, 383-396.

Weber, F.-A., Voegelin, A., Kretzschmar, R., 2009. Multi-metal contaminant dynamics in temporarily flooded soil under sulfate limitation. Geochim. Cosmochim. Acta 73, 5513-5527.

Wedepohl, K.H., 1995. The composition of the continental crust. Geochim. Cosmochim. Acta 59, 1217-1232.

Yang, M., Sañudo-Wilhelmy, S.A., 1998. Cadmium and manganese distributions in the Hudson River estuary: interannual and seasonal variability. Earth Planet Sci. Lett. $160,403-418$.

Zeri, C., Voutsinou-Taliadouri, F., 2003. Processes affecting the distribution of dissolved trace metals in the North Aegean Sea (Eastern Mediterranean). Cont. Shelf. Res. 23, 919-934.

Zwolsman, J.J.G., Van Eck, B.T.M., Van Der Weijden, C.H., 1997. Geochemistry of dissolved trace metals (cadmium, copper, zinc) in the Scheldt estuary, southwestern Netherlands: Impact of seasonal variability. Geochim. Cosmochim. Acta 61, 1635-1652. 